\title{
Article \\ Effects of Different Surface Heat Transfer Coefficients on Predicted Heating and Cooling Loads towards Sustainable Building Design
}

\author{
Yanwen $\mathrm{Wu}^{1,2}{ }^{\mathbb{D}}$, Wenna Jian ${ }^{1}$, Liu Yang ${ }^{1,2}$, Tengyue Zhang ${ }^{1,3}$ and Yan Liu ${ }^{1,2, *(D)}$ \\ 1 School of Architecture, Xi'an University of Architecture and Technology, Xi'an 710055, China; \\ wyw@xauat.edu.cn (Y.W.); jwn@xauat.edu.cn (W.J.); yangliu@xauat.edu.cn (L.Y.); ztyue1020@163.com (T.Z.) \\ 2 State Key Laboratory of Green Building in Western China, Xi'an University of Architecture and Technology, \\ Xi'an 710055, China \\ 3 Department of Architecture and Technology, Norwegian University of Science and Technology-NTNU, \\ NO-7491 Trondheim, Norway \\ * Correspondence: liuyan@xauat.edu.cn
}

check for updates

Citation: Wu, Y.; Jian, W.; Yang, L.; Zhang, T.; Liu, Y. Effects of Different Surface Heat Transfer Coefficients on Predicted Heating and Cooling Loads towards Sustainable Building Design. Buildings 2021, 11, 609. https:// doi.org/10.3390/buildings11120609

Academic Editors: Tao Wang,

Jian Zuo, Hanliang Fu and

Zezhou Wu

Received: 29 October 2021

Accepted: 30 November 2021

Published: 3 December 2021

Publisher's Note: MDPI stays neutral with regard to jurisdictional claims in published maps and institutional affiliations.

Copyright: (C) 2021 by the authors Licensee MDPI, Basel, Switzerland. This article is an open access article distributed under the terms and conditions of the Creative Commons Attribution (CC BY) license (https:// creativecommons.org/licenses/by/ $4.0 /)$.

\begin{abstract}
The transfer of surface heat between a building and the outdoor environment is the energy transfer channel and it is important for the energy efficiency of buildings. Early stage building design is a critical stage and it can directly determine the energy consumption by a building. Therefore, selecting appropriate surface heat transfer coefficients (SHTCs) is a key issue in building energy consumption prediction. In this study, EnergyPlus was employed to investigate the building load in Chinese cities with different SHTCs: (1) constant SHTCs based on national standards; and (2) dynamically changing SHTCs based on the Thermal Analysis Research Program (TARP). Based on investigations of the hourly load, daily cumulative load in a typical day, and annual cumulative load with different SHTCs, corrections for the annual cumulative load were obtained according to the relative deviations between the results produced with the TARP model and traditional SHTCs. The greatest relative deviations were $67.5 \%$ and $25.3 \%$ for the building shape factor $\varphi=0.49$ and 0.29 in Lhasa. The relative deviations were $13.3 \%$ and $12.0 \%$ for $\varphi=0.49$ in Xi'an and Beijing, respectively. Corrections were not essential for other conditions because the relative deviations were lower than $5.0 \%$. Considering the current characteristics of engineering calculations and the need to obtain more accurate design results, dynamically changing SHTCs should be applied. These correction factors can obtain more accurate results for the current building energy efficiency system with traditional SHTCs.
\end{abstract}

Keywords: sustainable building design; building energy efficiency; building load; early-stage design; EnergyPlus; surface heat transfer coefficient

\section{Introduction}

The building sector accounted for more than 35\% of the total energy consumed in China during 2020 [1]. Urban heat islands and high-density cities exacerbate this issue [2,3]. Corresponding standards have been developed to control the energy consumption and guide actual engineering applications, and the following two methods are generally applied in building energy efficiency design [4]. Method 1 involves setting limiting values for the thermal performance of a building (such as the heat transfer coefficient, window-wall ratio, and shape coefficient). Method 2 involves setting a limiting energy demand for a building (known as the trade-off option). Many basic field tests, numerical simulations, and theoretical analyses can be conducted to explore the relationships between the thermal performance of specific building components and the energy demand of a whole building.

In Method 1, the related limiting values are investigated step by step to achieve high energy efficiency. For instance, the heat transfer coefficient for walls in the related standard for the UK was reduced from $0.45 \mathrm{~W} / \mathrm{m}^{2} \mathrm{~K}$ in 1995 to $0.35 \mathrm{~W} / \mathrm{m}^{2} \mathrm{~K}$ in 2000 [5]. Recent 
investigations have aimed to further promote building energy efficiency. In particular, Delgarm et al. [6,7] studied a set of building energy efficiency and indoor thermal comfort solutions using a multi-objective optimization approach, where the predicted percentage dissatisfied decreased by $49.1-56.8 \%$ and the total energy consumption only increased by $2.9-11.3 \%$. Liu et al. [4] also proposed a building energy efficiency evaluation index to represent the energy-saving performance of buildings. Degree days obtained with the average daily indoor and outdoor air temperatures were used to eliminate the effects of envelopes on the building energy efficiency. However, it was difficult to represent the relationship between the thermal performance of envelopes and the energy consumption of the whole building based on degree days. Hence, the building energy consumption and building energy efficiency evaluation index were no longer suitable for representing the energy efficiency performance of building envelopes during the early stages of office building design.

In Method 2, a building design satisfies the requirements of the related standards. The American Society of Heating, Refrigerating and Air Conditioning Engineers (ASHRAE) Standard 90.1 in the US and Design Standard for Energy Efficiency of Public Buildings (GB 50189-2015) in China) when the energy consumption is less than or equal to that of the reference building, although one or several building thermal performance indexes might not meet the corresponding limiting values. In recent years, these standards have been improved continually and the building energy demand has decreased. The energy-saving rates for residential buildings in China were set as 30\%,50\%, and 65\% for GB 50189-1996, GB 50189-2005, and GB 50189-2010, respectively. Selecting appropriate surface heat transfer coefficients (SHTCs) is the key issue for accurate building load prediction. Constant internal and external SHTCs are usually employed in the current systems. Zhu et al. [8] determined the differences using DOE-2-based SHTCs and constant SHTCs with EnergyPlus software. The results indicated that the annual heating energy consumption with constant values was $14.0 \%$ higher than that with DOE-2, and the annual cooling energy consumption was $10.5 \%$ lower than that with DOE-2. Liu et al. [9] determined the correlations between the convective heat transfer coefficient (CHTC) based on the building density, wind speed, surface temperature, and temperature difference between the external surface and ambient temperature. The building cooling energy consumption increased by $4.0 \%$ and the heating energy consumption decreased by $1.3 \%$ as the building density increased from 0.04 to 0.44 . Mirsadeghi et al. [10] investigated the uncertainties regarding using different CHTCs and found that the differences in the annual cooling and heating energy consumption were up to $30.0 \%$ and $6.0 \%$, respectively. Thus, building energy consumption simulations were conducted based on different SHTCs rather than the building loads.

Selecting appropriate SHTCs is a crucial issue for building load prediction, and thus the determination of SHTCs has received much attention [11,12], where the methods used include experimental research, computational fluid dynamics (CFD) simulations, field tests, and theoretical analysis. The correlations obtained are compared in Figure 1 [10,11,13-16]. Yang et al. [17] conducted an annual four-season experimental investigation and determined the dynamic changes in the radiative heat, convective heat, total heat flow, and their proportions in different seasons. Koca and Cetin [18] obtained heat transfer coefficients for a heated radiant wall with average values of $8.57,5.74$, and $2.44 \mathrm{~W} \cdot \mathrm{m}^{-2} \cdot{ }^{\circ} \mathrm{C}^{-1}$ for the SHTC, radiative heat transfer coefficient, and CHTC, respectively. For phase change envelopes [19], the heat flux was assigned to different stages according to the phase change process, thereby leading to segmented SHTCs. To obtain SHTC measurements, Anderson. Ref. [20] illustrates the impact of building envelope on the optimal use of energy. Rui et al. [21] constructed a validated dynamic model for a heated gradient sensor to solve the problem caused by an unsteady-state convective airflow. Thus, experimental methods were established in these previous studies, and constant and dynamically changing values were obtained for building envelopes. In addition to experiments, numerical simulation investigations have been conducted. In particular, Liu et al. [22] investigated CHTCs for the external windward, leeward, lateral, and top surfaces of building arrays and found that 
large eddy simulation-based CHTCs were more accurate than those obtained by solving Reynolds-averaged Navier-Stokes equations. Kahsay et al. [23] used rectangular floor-plan building models with heights of 3, 10, 15, and 20-30 stories to derive the CHTC correlations based on the Reynolds numbers and building height. Blocken et al. [24] obtained the correlations between CHTCs with the wind speed and direction based on three-dimensional CFD simulations of a low-rise cubic building. Other studies investigated CHTCs according to the effects of the building geometry [25], by deriving new generalized expressions based on analytical formulas [26], by utilizing non-conformal grids [27], and the influence of oblique wind directions [28]. Costanzo et al. [29] found that the DOE-2 algorithm was much less accurate than the adaptive model for cool roofs when the solar reflectivity of the roof was low. Selçuk et al. [30] three building types are analyzed with a novel optimization approach, optimal results are produced for different goals in terms of energy-saving targets. These previous numerical and experimental investigations of SHTCs (CHTCs) have contributed significantly to our understanding of the heat transfer mechanism. However, these studies focused on the correlations with SHTCs under conventional or specific conditions, whereas the effects of different methods or algorithms for selecting SHTCs based on building loads have not been adequately assessed. Thus, the relationship between fundamental research and building energy efficiency design can be improved, and this was the focus of the present study.

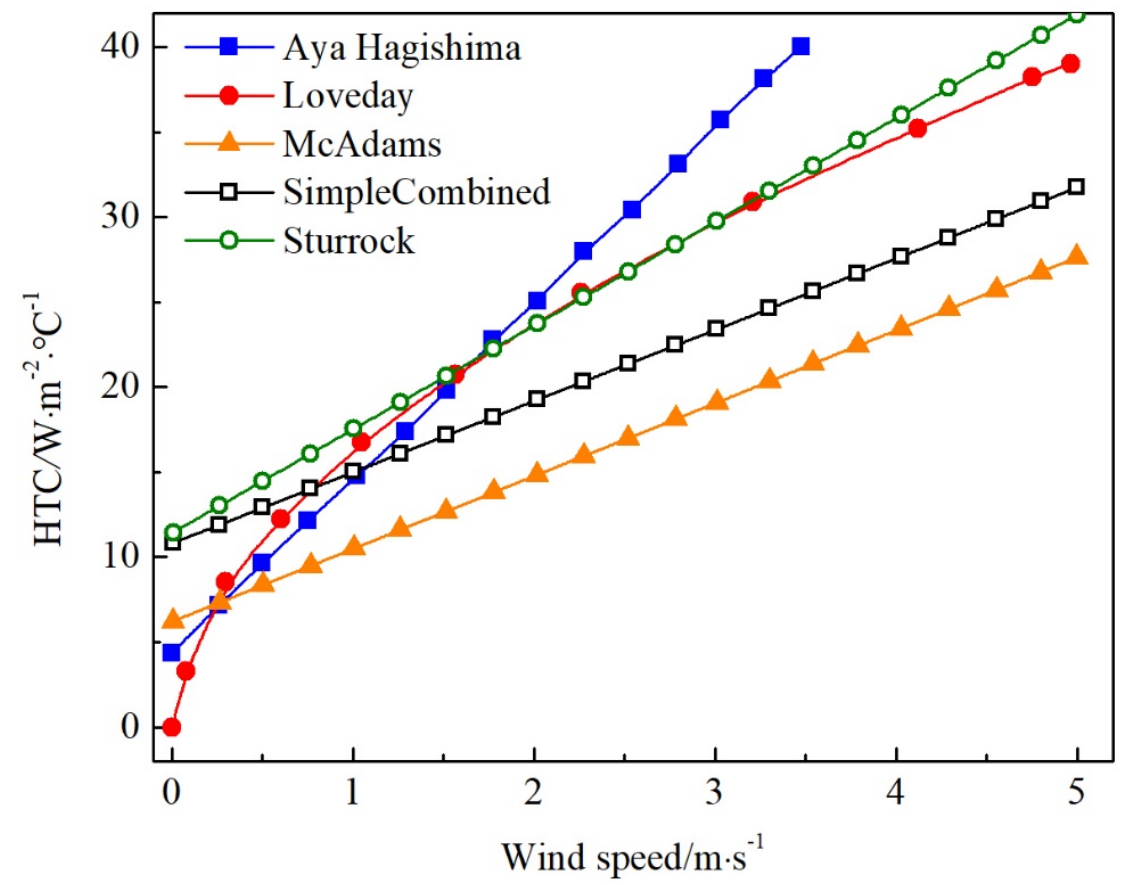

Figure 1. Comparisons between different surface heat transfer coefficients (SHTCs) (convective heat transfer coefficients, CHTCs).

Constant SHTCs are usually employed in engineering applications during the building development design stage. However, the effects of different SHTCs on building load predictions during early-stage office building design have rarely been studied. The corrected values are essential for establishing building load-based trade-off options. In the present study, the following options were investigated to determine the effects of different SHTCs on load predictions during early-stage office building design.

1. The hourly load behavior on a typical day in winter and summer was studied with different SHTCs.

2. The daily cumulative load behavior on a typical day in winter and summer was investigated with different SHTCs. 
3. The annual cumulative heating and cooling load behavior were examined with different SHTCs.

4. Finally, the annual cumulative loads were corrected based on the Thermal Analysis Research Program (TARP) model and compared with those using constant SHTCs.

\section{Methodology}

For the trade-off option, the thermal performance of the building components was only considered for the actual building model and reference building model in this study. However, the annual energy consumption is based on the annual cumulative load of heating, ventilation, and air conditioning (HVAC) systems, so the assessment results determined according to the annual energy consumption and building load for an actual building model and reference building model should be consistent for a HVAC system with the same efficiency (see Figure 2). Therefore, the building energy consumption could be replaced with the building load as the criterion for the trade-off option to simplify the process.

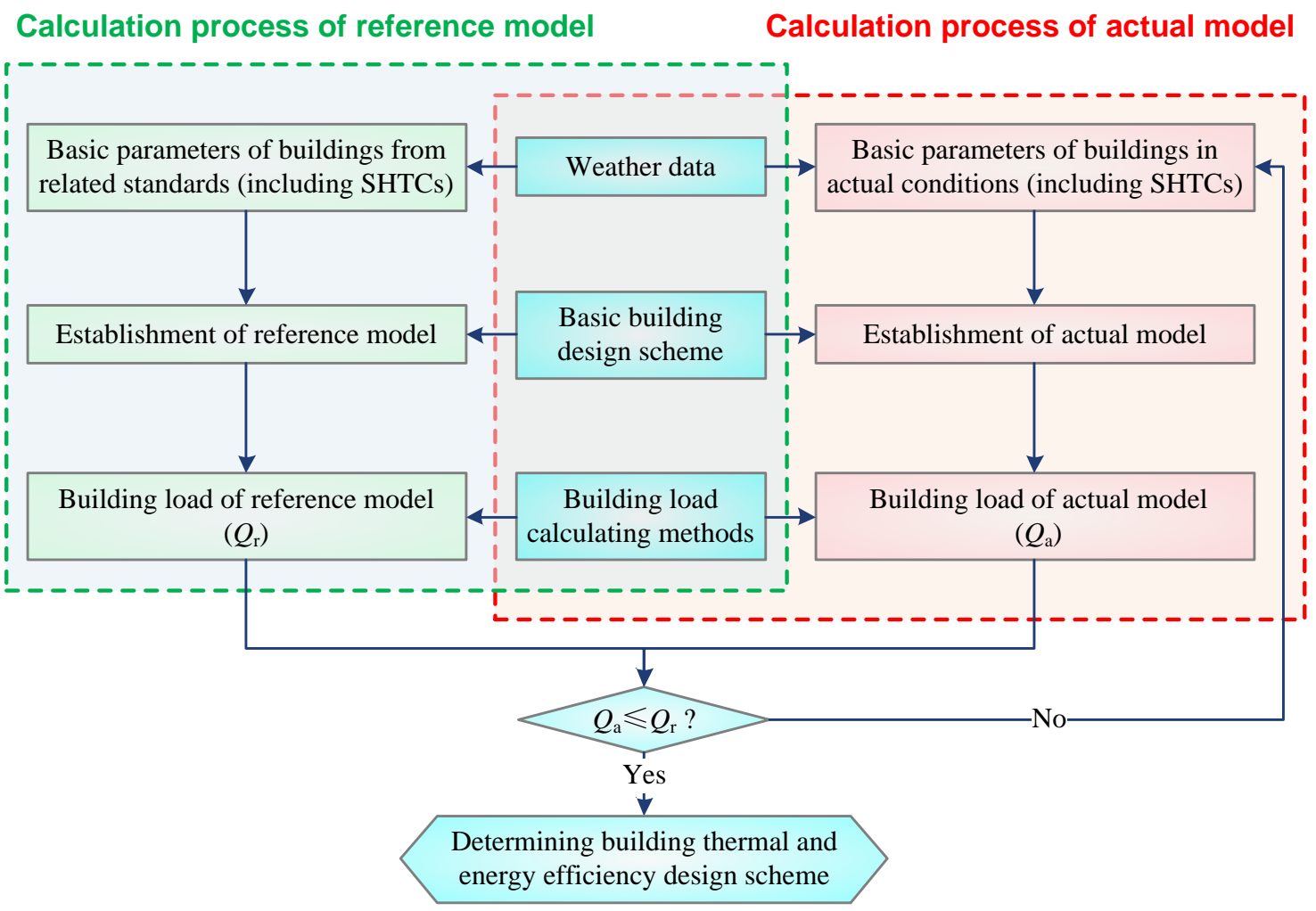

Figure 2. Building load-based trade-off option in building energy efficiency design.

\subsection{Representative Building}

The present study focused in office buildings in severely cold and cold climate zones in China. According to the national standard in China (Design Standard for Energy Efficiency of Public Buildings (GB 50189-2015)), the corresponding limiting values and energy efficiency performance were restricted to two levels based on different shape factors. Therefore, two typical office buildings were selected as representative buildings, as shown in Figure 3. The building model with the building shape factor $\varphi=0.49$ had a length of $16.0 \mathrm{~m}$, width of $10.0 \mathrm{~m}$, height of $6.0 \mathrm{~m}$, story height of $3.0 \mathrm{~m}$, and window-wall ratio of 0.2 (see Figure 3a,b). The building model with $\varphi=0.29$ had a length of $26.0 \mathrm{~m}$, width of $10.0 \mathrm{~m}$, height of $29.7 \mathrm{~m}$, story height of $3.3 \mathrm{~m}$, and window-wall ratio of 0.2 (see Figure $3 \mathrm{c}, \mathrm{d}$ ). The buildings faced south and the window-wall ratio was within the range recommended in the related standard. The building envelope constructions were those employed widely 
in cold and severely cold zones of China. The thermophysical properties of the building materials and their constructions are listed in Tables 1 and 2.

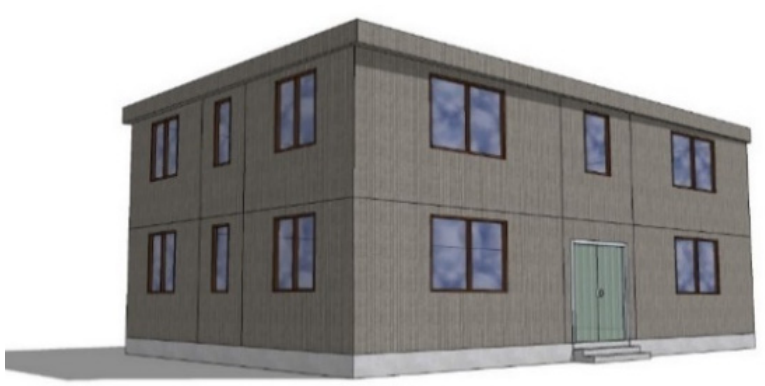

(a)

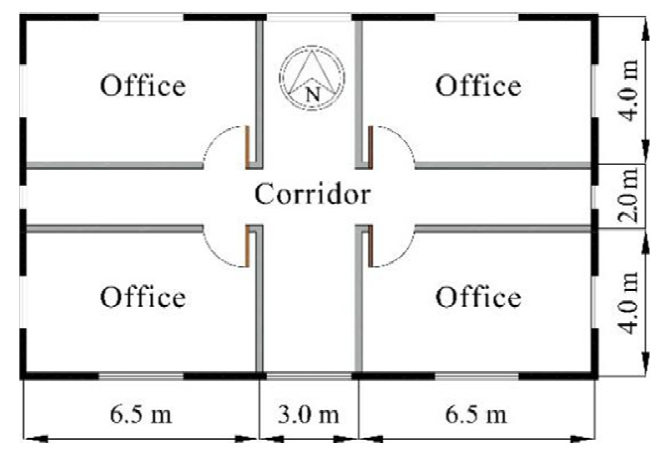

(b)

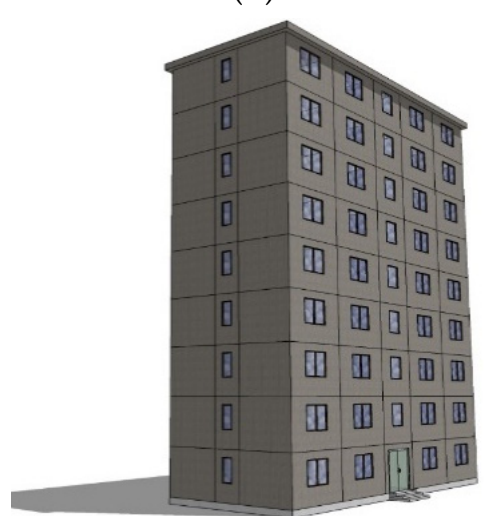

(c)

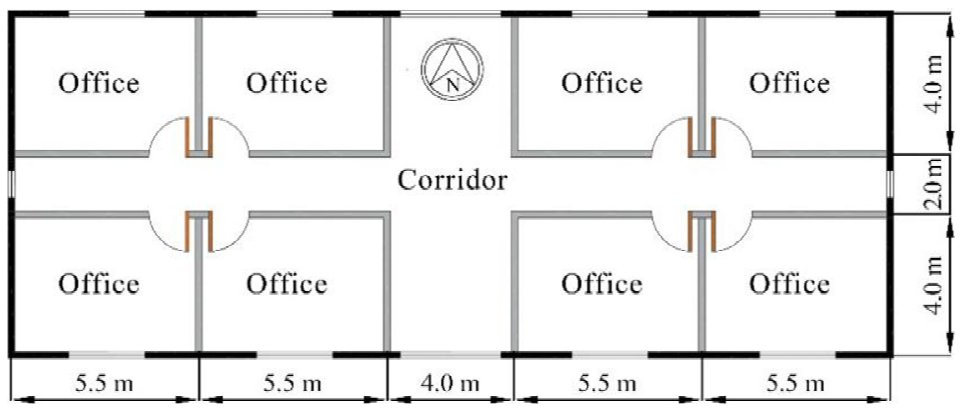

(d)

Figure 3. Building models and floor plans for the selected office buildings: (a) Building model with $\varphi=0.49$; (b) Floor plan with $\varphi=0.49$; (c) Building model with $\varphi=0.29$; (d) Floor plan with $\varphi=0.29$. 
Table 1. Thermophysical properties of building materials.

\begin{tabular}{|c|c|c|c|}
\hline Material & $\begin{array}{l}\text { Thermal Conductivity } \lambda \\
\left(\mathrm{W} \cdot \mathrm{m}^{-1} \cdot{ }^{\circ} \mathrm{C}^{-1}\right)\end{array}$ & $\begin{array}{l}\text { Density } \rho \\
\left(\mathbf{k g} \cdot \mathrm{m}^{-3}\right)\end{array}$ & $\begin{array}{c}\text { Specific Heat Capacity } c \\
\left(\mathrm{~J} \cdot \mathrm{kg}^{-1 .}{ }^{\circ} \mathrm{C}^{-1}\right)\end{array}$ \\
\hline Cement mortar & 0.930 & 1800 & 1050 \\
\hline Rigid polyurethane foam insulation board & 0.022 & 30 & 1380 \\
\hline Steam pressurized concrete blocks & 0.200 & 500 & 1005 \\
\hline Reinforced concrete & 1.740 & 2500 & 920 \\
\hline Lime-sand brick & 1.100 & 1900 & 1050 \\
\hline Polyurethane insulation board & 0.030 & 30 & 1380 \\
\hline Expanded polystyrene board & 0.049 & 20 & 1400 \\
\hline
\end{tabular}

Table 2. Details of the building envelopes.

\begin{tabular}{|c|c|c|c|}
\hline City & Shape Factor & Structure & Construction (from Outside to Inside) \\
\hline \multirow{4}{*}{ Xi'an } & \multirow[b]{2}{*}{0.49} & External wall & $\begin{array}{l}20 \mathrm{~mm} \text { cement mortar, } 100 \mathrm{~mm} \text { expanded polystyrene board, } 180 \mathrm{~mm} \\
\text { reinforced concrete, } 15 \mathrm{~mm} \text { cement mortar }\end{array}$ \\
\hline & & Roof & $\begin{array}{l}20 \mathrm{~mm} \text { cement mortar, } 30 \mathrm{~mm} \text { reinforced concrete, } 100 \mathrm{~mm} \text { steam } \\
\text { pressurized concrete block, } 65 \mathrm{~mm} \text { polyurethane insulation board, } \\
\qquad 30 \mathrm{~mm} \text { reinforced concrete }\end{array}$ \\
\hline & \multirow[b]{2}{*}{0.29} & External wall & $\begin{array}{l}20 \mathrm{~mm} \text { cement mortar, } 90 \mathrm{~mm} \text { expanded polystyrene board, } 180 \mathrm{~mm} \\
\text { reinforced concrete, } 15 \mathrm{~mm} \text { cement mortar }\end{array}$ \\
\hline & & Roof & $\begin{array}{l}20 \mathrm{~mm} \text { cement mortar, } 30 \mathrm{~mm} \text { reinforced concrete, } 100 \mathrm{~mm} \text { steam } \\
\text { pressurized concrete block, } 45 \mathrm{~mm} \text { polyurethane insulation board, } \\
\qquad 30 \mathrm{~mm} \text { reinforced concrete }\end{array}$ \\
\hline \multirow{4}{*}{ Beijing } & \multirow[b]{2}{*}{0.49} & External wall & $\begin{array}{l}20 \mathrm{~mm} \text { cement mortar, } 100 \mathrm{~mm} \text { expanded polystyrene board, } 180 \mathrm{~mm} \\
\text { reinforced concrete, } 15 \mathrm{~mm} \text { cement mortar }\end{array}$ \\
\hline & & Roof & $\begin{array}{l}20 \mathrm{~mm} \text { cement mortar, } 30 \mathrm{~mm} \text { reinforced concrete, } 100 \mathrm{~mm} \text { steam } \\
\text { pressurized concrete block, } 65 \mathrm{~mm} \text { polyurethane insulation board, } \\
\qquad 30 \mathrm{~mm} \text { reinforced concrete }\end{array}$ \\
\hline & \multirow[b]{2}{*}{0.29} & External wall & $\begin{array}{l}20 \mathrm{~mm} \text { cement mortar, } 90 \mathrm{~mm} \text { expanded polystyrene board, } 180 \mathrm{~mm} \\
\text { reinforced concrete, } 15 \mathrm{~mm} \text { cement mortar }\end{array}$ \\
\hline & & Roof & $\begin{array}{l}20 \mathrm{~mm} \text { cement mortar, } 30 \mathrm{~mm} \text { reinforced concrete, } 100 \mathrm{~mm} \text { steam } \\
\text { pressurized concrete block, } 45 \mathrm{~mm} \text { polyurethane insulation board, } \\
30 \mathrm{~mm} \text { reinforced concrete }\end{array}$ \\
\hline \multirow{4}{*}{ Urumqi } & \multirow[b]{2}{*}{0.49} & External wall & $\begin{array}{l}20 \mathrm{~mm} \text { cement mortar, } 70 \mathrm{~mm} \text { rigid polyurethane foam insulation } \\
\text { board, } 180 \mathrm{~mm} \text { reinforced concrete, } 15 \mathrm{~mm} \text { cement mortar }\end{array}$ \\
\hline & & Roof & $\begin{array}{l}20 \mathrm{~mm} \text { cement mortar, } 30 \mathrm{~mm} \text { reinforced concrete, } 100 \mathrm{~mm} \text { steam } \\
\text { pressurized concrete block, } 90 \mathrm{~mm} \text { polyurethane insulation board, } \\
30 \mathrm{~mm} \text { reinforced concrete }\end{array}$ \\
\hline & \multirow[b]{2}{*}{0.29} & External wall & $\begin{array}{l}20 \mathrm{~mm} \text { cement mortar, } 100 \mathrm{~mm} \text { expanded polystyrene board, } 180 \mathrm{~mm} \\
\text { reinforced concrete, } 15 \mathrm{~mm} \text { cement mortar }\end{array}$ \\
\hline & & Roof & $\begin{array}{l}20 \mathrm{~mm} \text { cement mortar, } 30 \mathrm{~mm} \text { reinforced concrete, } 100 \mathrm{~mm} \text { steam } \\
\text { pressurized concrete block, } 65 \mathrm{~mm} \text { polyurethane insulation board, } \\
30 \mathrm{~mm} \text { reinforced concrete }\end{array}$ \\
\hline \multirow{4}{*}{ Lhasa } & \multirow{2}{*}{0.49} & External wall & $\begin{array}{l}20 \mathrm{~mm} \text { cement mortar, } 100 \mathrm{~mm} \text { expanded polystyrene board, } 180 \mathrm{~mm} \\
\text { reinforced concrete, } 15 \mathrm{~mm} \text { cement mortar }\end{array}$ \\
\hline & & Roof & $\begin{array}{l}20 \mathrm{~mm} \text { cement mortar, } 30 \mathrm{~mm} \text { reinforced concrete, } 100 \mathrm{~mm} \text { steam } \\
\text { pressurized concrete block, } 65 \mathrm{~mm} \text { polyurethane insulation board, } \\
30 \mathrm{~mm} \text { reinforced concrete }\end{array}$ \\
\hline & \multirow[b]{2}{*}{0.29} & External wall & $\begin{array}{l}20 \mathrm{~mm} \text { cement mortar, } 90 \mathrm{~mm} \text { expanded polystyrene board, } 180 \mathrm{~mm} \\
\text { reinforced concrete, } 15 \mathrm{~mm} \text { cement mortar }\end{array}$ \\
\hline & & Roof & $\begin{array}{l}20 \mathrm{~mm} \text { cement mortar, } 30 \mathrm{~mm} \text { reinforced concrete, } 100 \mathrm{~mm} \text { steam } \\
\text { pressurized concrete block, } 45 \mathrm{~mm} \text { polyurethane insulation board, } \\
30 \mathrm{~mm} \text { reinforced concrete }\end{array}$ \\
\hline
\end{tabular}


Table 2. Cont.

\begin{tabular}{|c|c|c|c|}
\hline City & Shape Factor & Structure & Construction (from Outside to Inside) \\
\hline \multirow{4}{*}{ Mohe } & \multirow{2}{*}{0.49} & External wall & $\begin{array}{l}20 \mathrm{~mm} \text { cement mortar, } 75 \mathrm{~mm} \text { rigid polyurethane foam insulation } \\
\text { board, } 180 \mathrm{~mm} \text { reinforced concrete, } 15 \mathrm{~mm} \text { cement mortar }\end{array}$ \\
\hline & & Roof & $\begin{array}{l}20 \mathrm{~mm} \text { cement mortar, } 30 \mathrm{~mm} \text { reinforced concrete, } 100 \mathrm{~mm} \text { steam } \\
\text { pressurized concrete block, } 100 \mathrm{~mm} \text { polyurethane insulation board, } \\
30 \mathrm{~mm} \text { reinforced concrete }\end{array}$ \\
\hline & \multirow[b]{2}{*}{0.29} & External wall & $\begin{array}{l}20 \mathrm{~mm} \text { cement mortar, } 70 \mathrm{~mm} \text { rigid polyurethane foam insulation } \\
\text { board, } 180 \mathrm{~mm} \text { reinforced concrete, } 15 \mathrm{~mm} \text { cement mortar }\end{array}$ \\
\hline & & Roof & $\begin{array}{l}20 \mathrm{~mm} \text { cement mortar, } 30 \mathrm{~mm} \text { reinforced concrete, } 100 \mathrm{~mm} \text { steam } \\
\text { pressurized concrete block, } 90 \mathrm{~mm} \text { polyurethane insulation board, } \\
\qquad 30 \mathrm{~mm} \text { reinforced concrete }\end{array}$ \\
\hline \multirow{3}{*}{ All cities } & \multirow{3}{*}{ All shape factors } & Internal wall & $\begin{array}{l}20 \mathrm{~mm} \text { cement mortar, } 240 \mathrm{~mm} \text { lime-sand brick, } \\
20 \mathrm{~mm} \text { cement mortar }\end{array}$ \\
\hline & & Floor slab & $\begin{array}{l}5 \mathrm{~mm} \text { cement mortar, } 100 \mathrm{~mm} \text { reinforced concrete, } \\
5 \mathrm{~mm} \text { cement mortar }\end{array}$ \\
\hline & & Floor & $\begin{array}{c}20 \mathrm{~mm} \text { cement mortar, } 50 \mathrm{~mm} \text { expanded polystyrene board, } 120 \mathrm{~mm} \\
\text { reinforced concrete }\end{array}$ \\
\hline
\end{tabular}

\subsection{Simulation Process}

EnergyPlus 8.7 [31] was mainly developed by the US Department of Energy and National Renewable Energy Laboratory and it was employed to conduct numerical simulations in this study. Several models can be used to describe dynamically changing external SHTCs, including TARP, MoWiTT (Mobile Windows Thermal Test), DOE-2, and SimpleCombined. TARP, Simple Natural Convection, and Ceiling Diffuser were developed for internal SHTCs. The TARP model considers the wind speed and surface roughness, as well as the differences between natural and forced convection, the direction of heat flux, and wind along the building surface $[18,32,33]$. The researchers have shown that the predictions of BLAST are very close to the actual measurements [34,35]. The TARP algorithm was derived from the ASHRAE literature by Walton (1983), and was in good agreement with the curve fitting values of BLAST simulation results, as shown in Figure 4 [36,37]. Therefore, the TARP model was used for comparison with the results produced based on constant SHTCs to obtain more reliable results. The SHTCs at the internal and external surfaces are defined as follows:

$$
\begin{aligned}
h_{\mathrm{in}} & =h_{\mathrm{in}, \mathrm{c}}+h_{\mathrm{in}, \mathrm{r}} \\
h_{\mathrm{out}} & =h_{\mathrm{out}, \mathrm{c}}+h_{\mathrm{out}, \mathrm{r}}
\end{aligned}
$$

where $h_{\text {in }}$ and $h_{\text {out }}$ are the SHTCs at the internal and external surfaces, respectively, $\mathrm{W} \cdot \mathrm{m}^{-2} \cdot{ }^{\circ} \mathrm{C}^{-1} ; h_{\mathrm{in}, \mathrm{c}}$ and $h_{\mathrm{in}, \mathrm{r}}$ are the convection and radiation components of $h_{\mathrm{in}} ;$ and $h_{\mathrm{out}, \mathrm{c}}$ and $h_{\text {out,r }}$ are the convection and radiation components of $h_{\text {out }}$ [38]. 


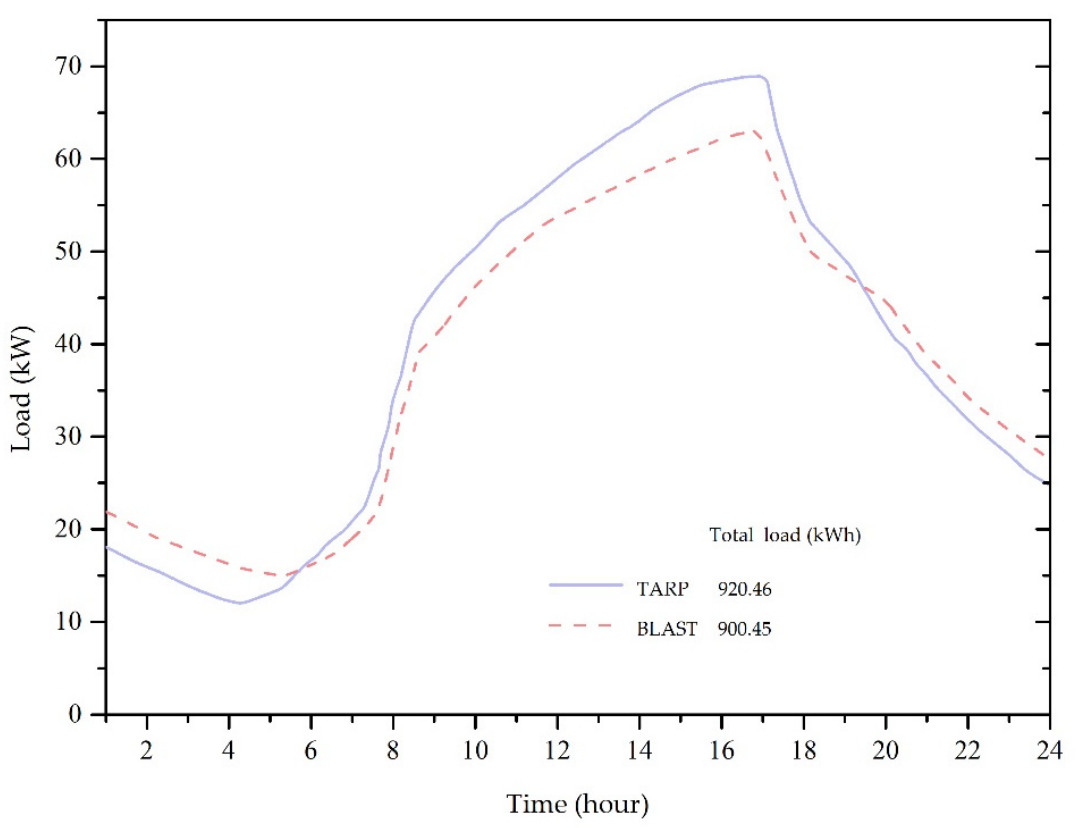

Figure 4. Comparison between the estimations of the BLAST and Thermal Analysis Research Program (TARP) programs for an office space on summer design day.

The natural convection component $h_{\mathrm{in}, \mathrm{n}}$ was only considered for $h_{\mathrm{in}, \mathrm{c}}$. For the external side, both the natural $h_{\text {out,n }}$ and forced convection components $h_{\text {out,f }}$ were considered for $h_{\text {out,c }}$, which are given as follows.

$$
\begin{gathered}
h_{\mathrm{in}, \mathrm{c}}=h_{\mathrm{in}, \mathrm{n}} \\
h_{\mathrm{out}, \mathrm{c}}=h_{\text {out }, \mathrm{n}}+h_{\mathrm{out}, \mathrm{f}}
\end{gathered}
$$

The natural components $h_{\text {in\&out,n }}$ of TARP-based CHTCs were determined using the temperature difference and direction of the facing surface, as follows:

$$
\left\{\begin{array}{l}
h_{\text {in\&out, } \mathrm{n}}=1.31 \cdot|\Delta T|^{0.33} \\
\text { when } \Delta T=0 \text { or for a vertical surface } \\
h_{\text {in\&out, } \mathrm{n}}=\frac{9.48 \cdot|\Delta T|^{0.33}}{6.28} \\
\text { when } \Delta T<0 \text { for an upward facing surface, or } \Delta T>0 \text { for a downward facing surface } \\
h_{\text {in\&out, } \mathrm{n}}=\frac{1.81 \cdot|\Delta T|^{0.33}}{2.38} \\
\text { when } \Delta T>0 \text { for an upward facing surface, or } \Delta T<0 \text { for a downward facing surface }
\end{array}\right.
$$

where $\Delta T$ is the temperature difference between the surface and the air $\left({ }^{\circ} \mathrm{C}\right)$.

The forced components of TARP-based CHTCs were calculated with a correlation proposed by Sparrow, Ramsey, and Mass, which is expressed as follows:

$$
h_{\text {out }, \mathrm{f}}=2.54 \cdot W_{\mathrm{f}} \cdot R_{\mathrm{f}} \cdot\left(\frac{P \cdot V_{\mathrm{z}}}{A}\right)^{0.5}
$$

where $W_{\mathrm{f}}$ is the fitting coefficient, i.e., 1.0 for windward surfaces and 0.5 for leeward surfaces; $P$ is the perimeter of the surface, $\mathrm{m} ; V_{\mathrm{z}}$ is the local wind speed calculated at the height above ground of the surface centroid, $\mathrm{m} \cdot \mathrm{s}^{-1} ; A$ is the surface area of the surface, $\mathrm{m}^{2}$; and $R_{\mathrm{f}}$ is the surface roughness multiplier, which is based on the ASHRAE graph of surface conductance, as shown in Table 3.

$$
\begin{gathered}
h_{\mathrm{in}, \mathrm{r}}=\varepsilon \cdot \sigma \cdot\left(T_{\mathrm{in}, \mathrm{s}}^{2}+T_{\text {in.air }}^{2}\right)\left(T_{\mathrm{in}, \mathrm{s}}+T_{\mathrm{in}, \text { air }}\right) \\
h_{\mathrm{out}, \mathrm{r}}=\varepsilon \cdot \sigma \cdot\left(T_{\text {out }, \mathrm{s}}^{2}+T_{\text {out.air }}^{2}\right)\left(T_{\mathrm{out}, \mathrm{s}}+T_{\text {out,air }}\right)
\end{gathered}
$$


where $\sigma$ is the Stefan-Boltzmann constant; $\varepsilon$ are the hemispherical emissivities of the surfaces bounding the airspace; $T_{\mathrm{in}, \mathrm{s}}$ and $T_{\mathrm{in}, \text { air }}$ are the internal wall surface temperature and air temperature; $T_{\text {out,s }}$ and $T_{\text {out,air }}$ are the external wall surface temperature and air temperature. For comparative studies on a typical day with constant SHTCs, the values at the external surface were $23 \mathrm{~W} \cdot \mathrm{m}^{-2} \cdot{ }^{\circ} \mathrm{C}^{-1}$ in winter and $19 \mathrm{~W} \cdot \mathrm{m}^{-2} \cdot{ }^{\circ} \mathrm{C}^{-1}$ in summer. The value at the internal surface was set at $8.7 \mathrm{~W} \cdot \mathrm{m}^{-2} \cdot{ }^{\circ} \mathrm{C}^{-1}$ for both typical days. For annual cumulative heating and cooling load comparisons with constant SHTCs, the values at the external surface were 23 and $19 \mathrm{~W} \cdot \mathrm{m}^{-2} \cdot{ }^{\circ} \mathrm{C}^{-1}$, respectively. The value at the internal surface was set at $8.7 \mathrm{~W} \cdot \mathrm{m}^{-2} \cdot{ }^{\circ} \mathrm{C}^{-1}$ all year-round. All of the settings above were selected according to the Code for thermal design of the civil building (GB 50176-2016). The conduction transfer function (CTF) algorithm was employed to solve the heat transfer in building envelopes, as defined in GB 50176-2016. According to the engineering reference for EnergyPlus [39], the time step was selected as $1 \mathrm{~h}$. Weather data comprised the typical meteorological year (TMY) integrated with EnergyPlus [40]. The typical day was 21 January in winter (the indoor temperature was $18^{\circ} \mathrm{C}$ for calculations) and 21 July in summer (the indoor temperature was $26^{\circ} \mathrm{C}$ for calculations). For the annual cumulative heating and cooling load comparisons, the indoor temperatures for calculations were $18{ }^{\circ} \mathrm{C}$ and $26^{\circ} \mathrm{C}$, respectively. The hourly occupancy rate, lighting power density, and equipment power density were $15 \mathrm{~W} / \mathrm{m}^{2}$, air change rate were 0.7 ach, according to related standards.

Table 3. Surface roughness multipliers.

\begin{tabular}{ccc}
\hline Roughness & $\boldsymbol{R}_{\mathbf{f}}$ & Example \\
\hline Very rough & 2.17 & Stucco \\
Rough & 1.67 & Brick \\
Medium rough & 1.52 & Concrete \\
Medium smooth & 1.13 & Clean pine \\
Smooth & 1.11 & Smooth plaster \\
Very smooth & 1.00 & Glass \\
\hline
\end{tabular}

The calculation formula of the envelope U-values was as follows:

$$
\begin{aligned}
& U_{V H T C}=\frac{1}{\frac{1}{h_{\text {in }}}+\sum\left(\frac{d}{\lambda}\right)+\frac{1}{h_{\text {out }}}} \\
& U_{C H T C, W}=\frac{1}{\frac{1}{8.7}+\frac{1}{23}+\sum\left(\frac{d}{\lambda}\right)} \\
& U_{C H T C, S}=\frac{1}{\frac{1}{8.7}+\frac{1}{19}+\sum\left(\frac{d}{\lambda}\right)}
\end{aligned}
$$

where $U_{V H T C}, U_{C H T C, W}$ and $U_{C H T C, S}$ are the envelope U-values in the variable HTC model, constant HTC model in winter and constant HTC model in summer respectively; $d$ is the thickness of the corresponding building material, $\lambda$ is the thermal conductivity.

\subsection{Climate Analysis}

According to the "General Principles of Civil Building Design", the five cities selected for investigation from the severely cold zone and cold zone were Mohe, Urumqi, Beijing, $\mathrm{Xi}^{\prime}$ an, and Lhasa. The locations and annual average temperature and humidity values are shown in Figure 5. Xi'an, Beijing, and Lhasa are located in the cold zone. Xi'an and Beijing have similar climate characteristics, except for differences in the cold and hot temperatures. Lhasa is located on the Tibetan Plateau at an altitude of more than $3000 \mathrm{~m}$, with abundant sunshine, intense solar radiation, and comfortable summers. The calculation of the heat load demand was mainly considered in the winter. Mohe and Urumqi are located in the severely cold zone, where the daily temperature range and annual temperature range are 
relatively large. Urumqi is cold and dry, and Mohe is located in a high latitude region. The significant temperature differences greatly affected the cold and heat load calculations.

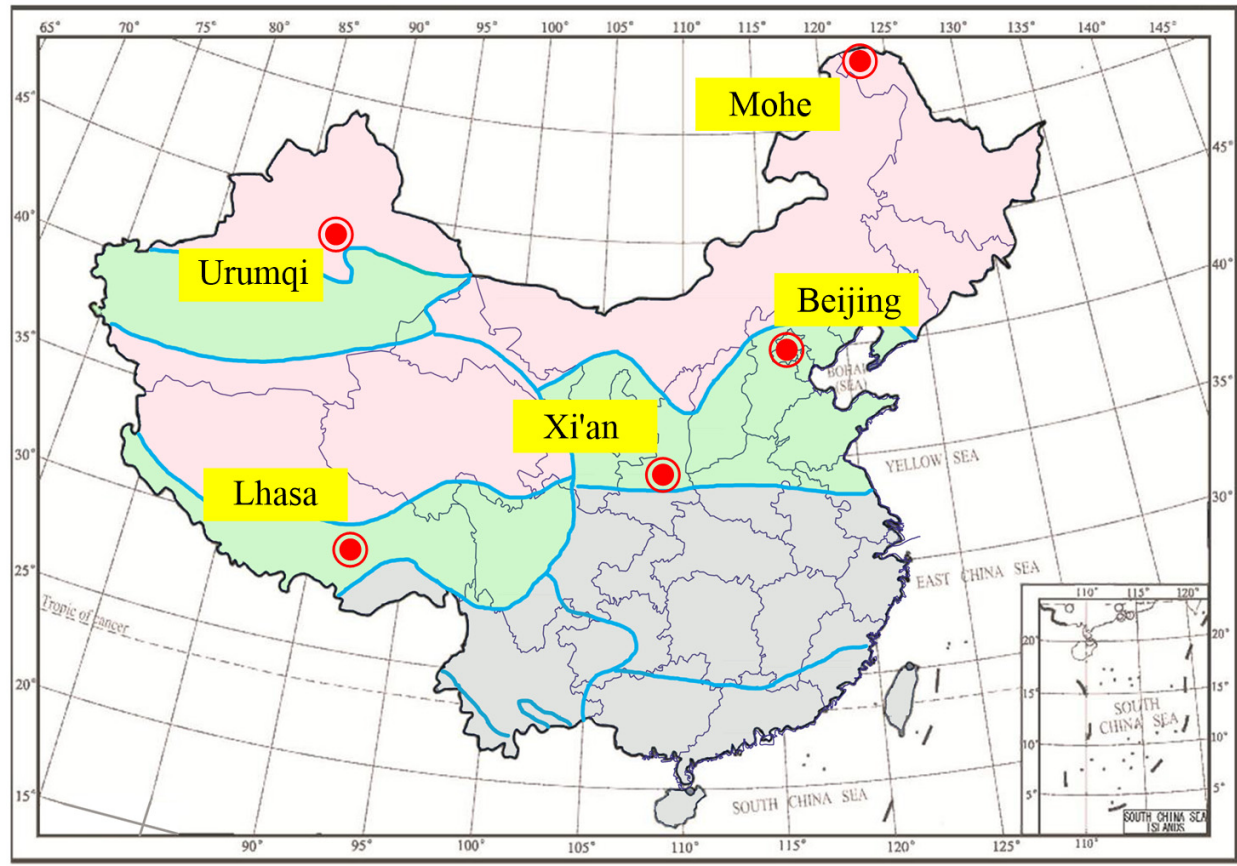

Severe cold zone

Cold zone

Five selected cities

(a)

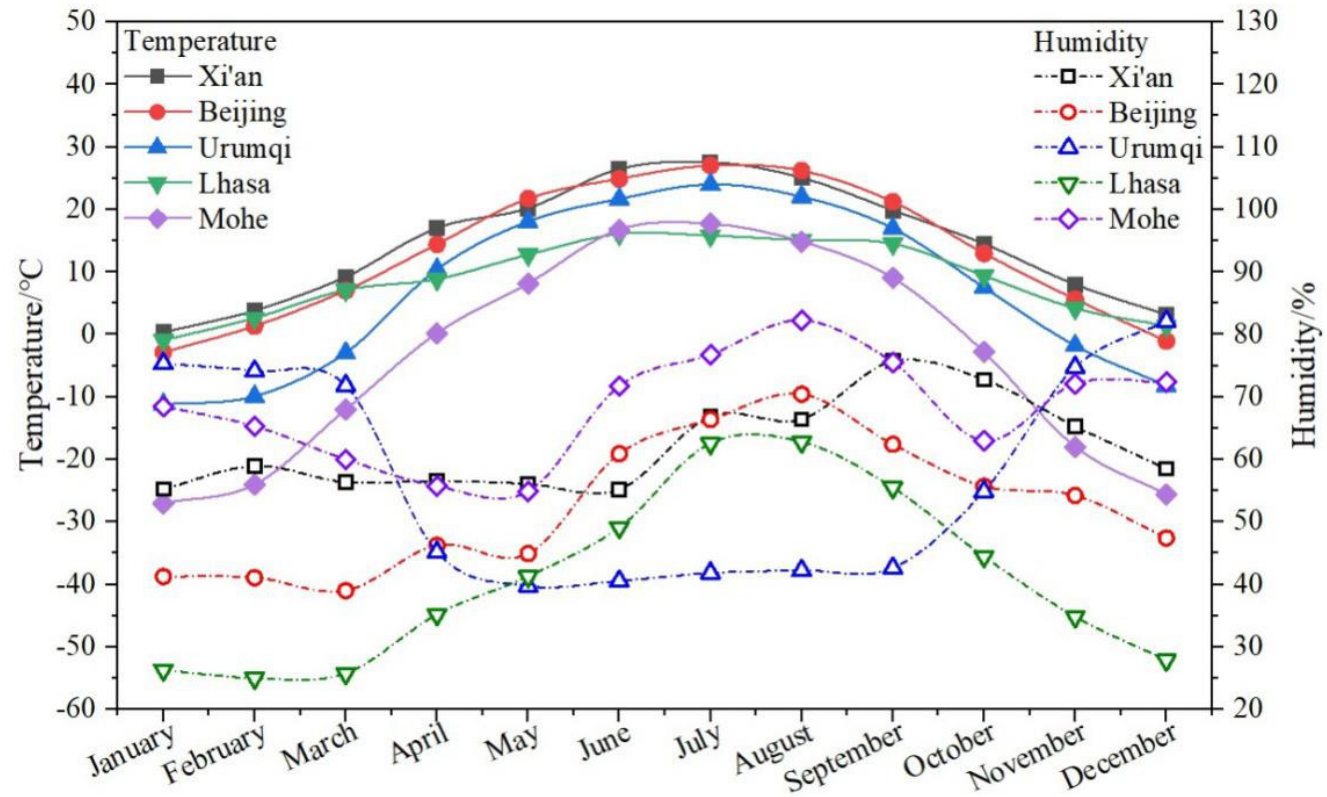

(b)

Figure 5. Climate characteristics of the five selected cities: (a) Locations of five selected cities; (b) Average temperature and humidity values in TMY. 


\section{Results and Discussion}

This study investigated the building hourly load behavior on a typical day, daily cumulative load behavior, and corrections of the annual cumulative load for different SHTCs, shape factors, and locations.

\subsection{Hourly Load Behavior on a Typical Day}

The building model with $\varphi=0.49$ for $\mathrm{Xi}^{\prime}$ an in the cold zone in China was selected as an example. The hourly load behavior with different internal SHTCs on a typical day is illustrated in Figure 6. Different SHTCs at the internal surface are presented in Figure 6 for reference. For a typical day in winter and the selected building, the trend in the hourly heating load was consistent with that in the SHTCs. In particular, the hourly heating load tended to decrease from 6:00 and it decreased to 0 at 8:00. The value then remained at 0 until 20:00 because the running periods for lighting and electrical equipment were set from 7:00 to 19:00, as described in previous studies, which was equivalent to an internal heat source that could release heat to the indoor environment. The heat was released after 19:00 to reduce the heating load due to heat charge and discharge effects by the building envelopes. Therefore, the heating load exhibited a downward trend or it even decreased to 0 from 7:00 to 19:00. The maximum relative deviation was 128.7\% at 1:00 and the average deviation was $52.0 \%$. For a typical day in summer and the selected building, the trend in the hourly heating load also remained constant with different SHTCs (see Figure 6b). The deviations between the hourly cooling loads with different SHTCs were much smaller (average relative deviation $=3.2 \%$ ) than those for a typical winter day. At 20:00, the hourly cooling load had a maximum deviation of $15.0 \%$.

The hourly load behavior with different external SHTCs on a typical day is illustrated in Figure 7. The hourly heating load on a typical day in winter for the selected room calculated using the TARP model was lower than the constant SHTCs for the whole day (the maximum deviation of 51.9\% occurred at 1:00) because of low heat losses in the winter due to low SHTCs. For a typical day in summer, the results were similar to those presented in Figure 6b. However, the differences in the hourly cooling load on a typical summer day were much lower than those in the hourly heating load with different SHTCs. Thus, the effects of SHTCs on the hourly heating load were more significant than those on the hourly cooling load.

Finally, the hourly load behavior was examined with different internal and external SHTCs on a typical day, as shown in Figure 8. The results presented in Figure 8 comprise the superposition of Figures 6 and 7. For a typical day in winter, the hourly heating load was much larger with the TARP model than that with constant values. The maximum deviation of $110.0 \%$ occurred at 20:00. For a typical day in summer, the results were similar to those in other severely cold and cold climate zones in China under different calculation conditions. The heating load generally attracted more attention for Xi'an in China. In addition, the study methods could be duplicated for other selected cities. Therefore, the daily load behavior was examined with different SHTCs on a typical day. 


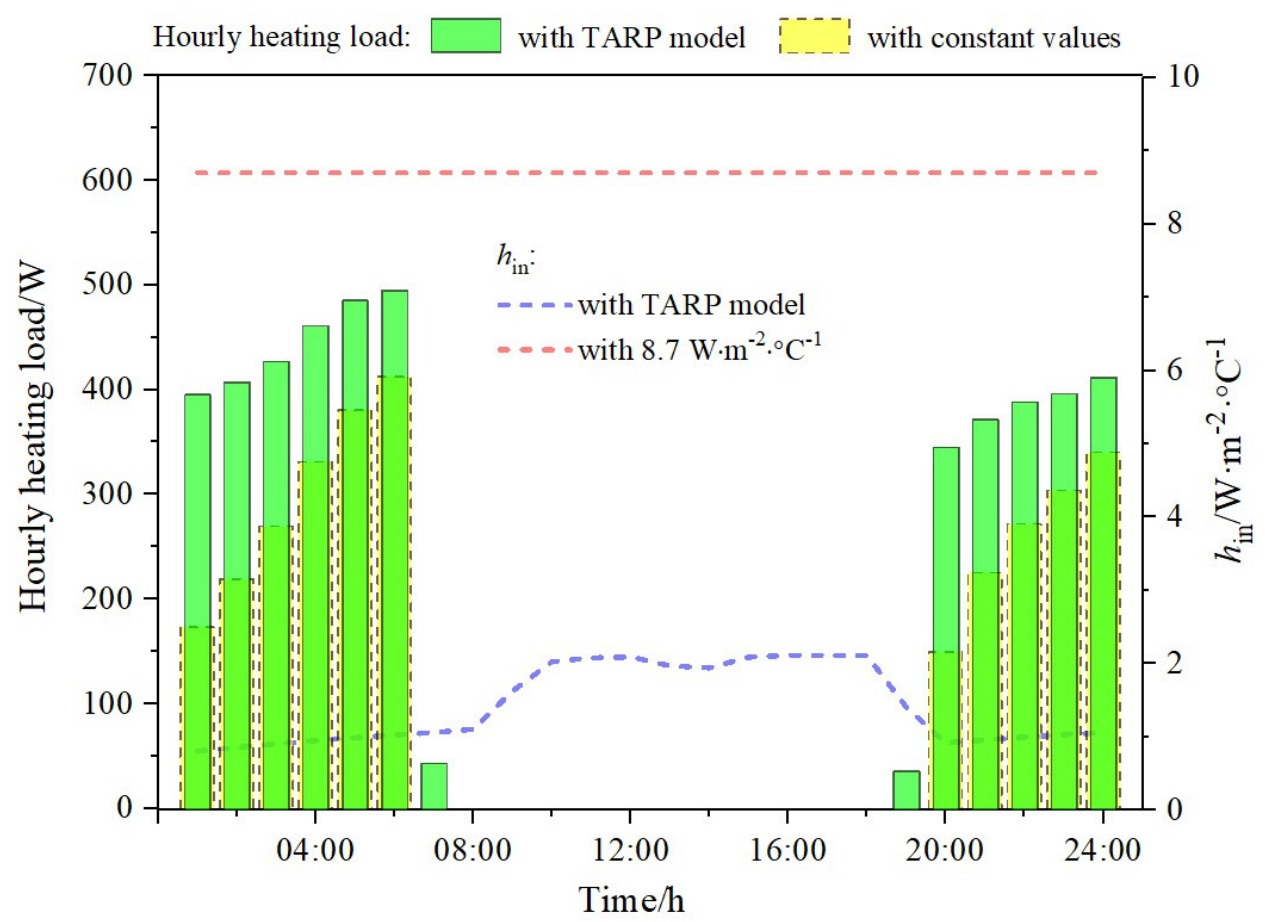

(a)

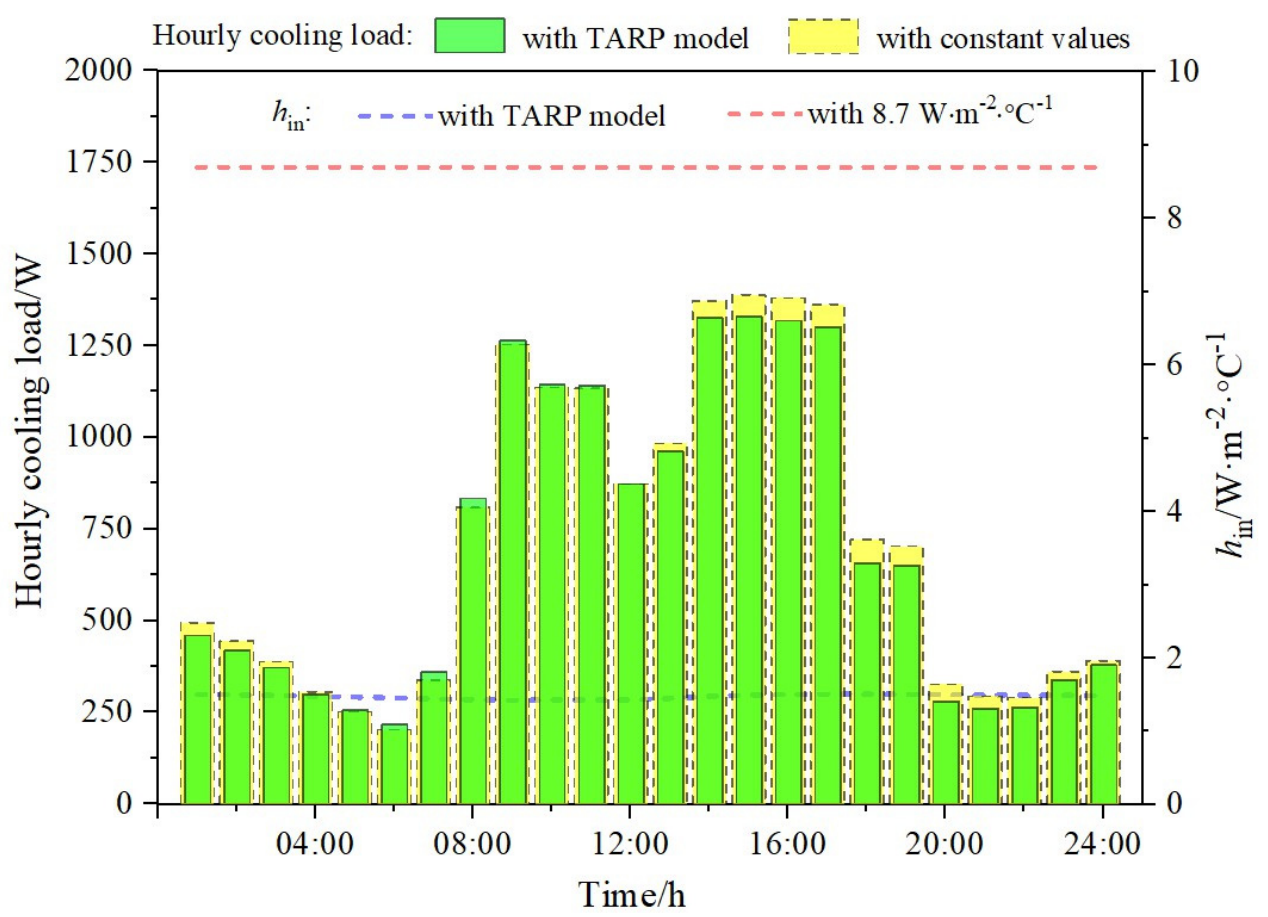

(b)

Figure 6. Comparisons of hourly loads with different internal SHTCs on a typical day: (a) Hourly heating load on a typical day in winter; (b) Hourly cooling load on a typical day in summer. 


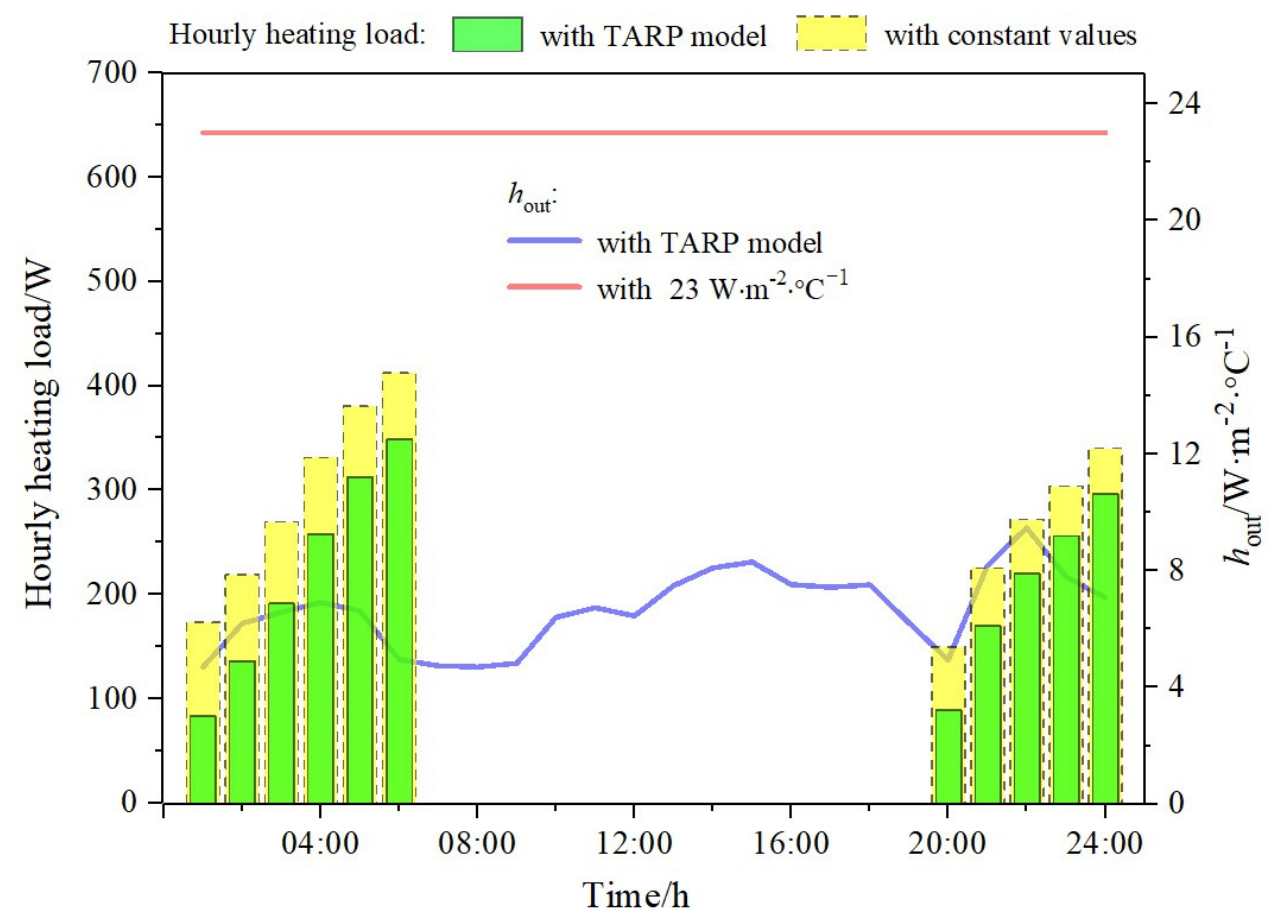

(a)

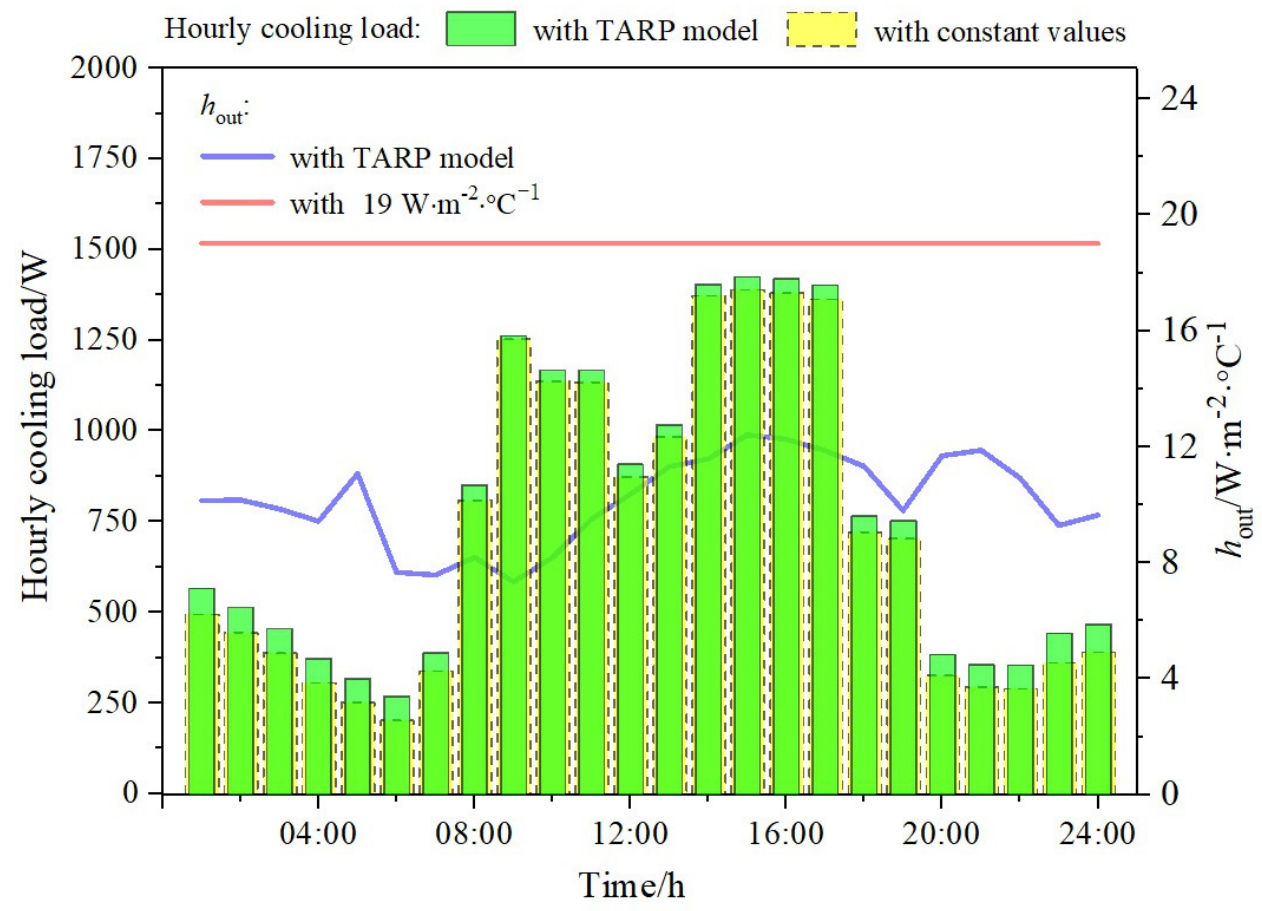

(b)

Figure 7. Comparisons of hourly loads with different external SHTCs on a typical day: (a) Hourly heating load on a typical day in winter; (b) Hourly cooling load on a typical day in summer. 


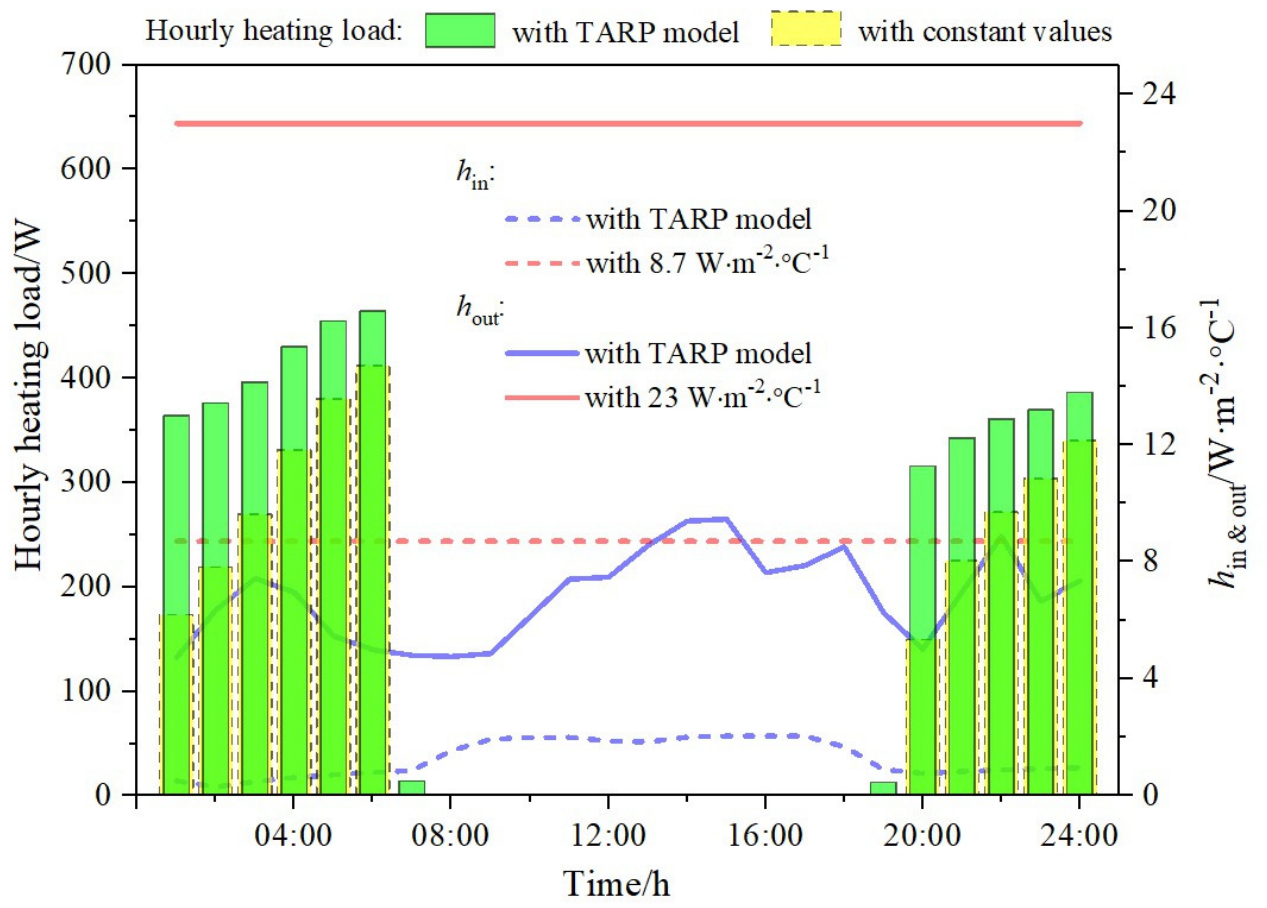

(a)

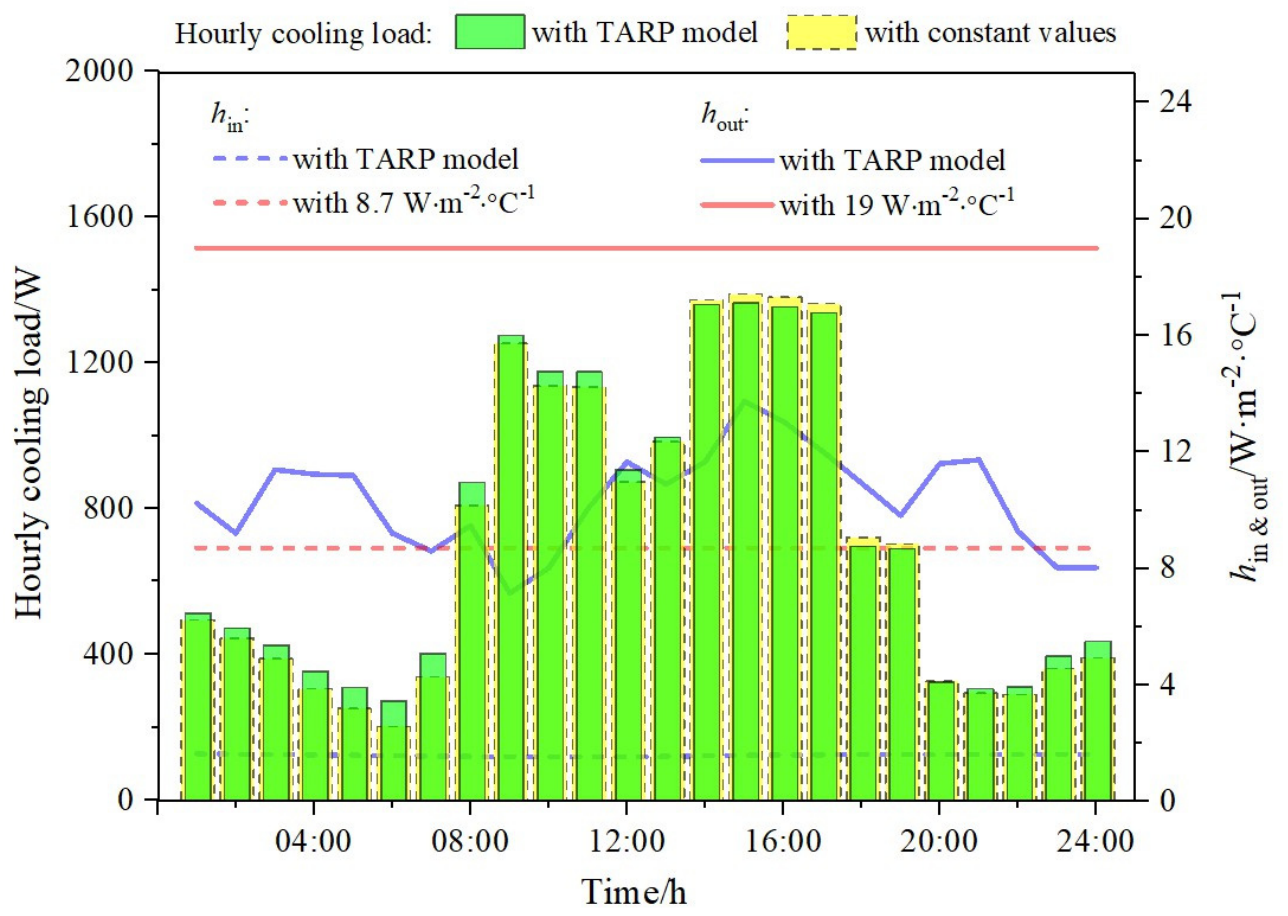

(b)

Figure 8. Comparisons of hourly loads with different internal and external SHTCs on a typical day: (a) Hourly heating load on a typical day in winter; (b) Hourly cooling load on a typical day in summer. 


\subsection{Daily Cumulative Load Behavior on a Typical Day}

The effects of different shape factors and locations on the daily cumulative loads of whole buildings were studied. The relative deviations in the daily cumulative load with TARP-based internal SHTCs and constant SHTCs are illustrated in Figure 9a. For a typical day in winter, the effects of SHTCs on the daily cumulative load behavior were moderate in all cities except Lhasa. For $\varphi=0.49$, a relative deviation of $60.3 \%$ was observed in Lhasa. Among all of the other cities, the largest relative deviation occurred in Xi'an, with a value of $16.6 \%$. For $\varphi=0.29$, the relative deviation was lower than $12.4 \%$ in all other cities, which was very different from the result for Lhasa. For a typical day in summer, relatively large relative deviations in the daily cumulative load were observed in Lhasa and Urumqi for $\varphi=0.49$, i.e., $30.9 \%$ and $23.1 \%$, respectively. For all of the other cities, the relative deviation was lower than $20 \%$. For $\varphi=0.29$, a relative deviation lower than $12.1 \%$ was observed in all cities. In most conditions, the relative deviation increased as the shape factor increased.

The relative deviations in the daily cumulative load results with TARP-based external SHTCs and constant SHTCs are shown in Figure $9 \mathrm{~b}$. A relatively significant difference was observed in Lhasa for both shape factors $(42.7 \%$ and $35.9 \%$ on a typical winter day, and $26.8 \%$ and $11.3 \%$ on a typical summer day). In other cities, the deviations between the different external SHTCs for cumulative heating and cooling loads were lower than $15 \%$ on a typical day. A comparison of Figure 9a,b shows that the internal SHTCs had a greater influence than the external SHTCs.

The relative deviations in the daily cumulative load results with TARP-based internal and external SHTCs and constant SHTCs are shown in Figure 9c. The results demonstrate the comprehensive effects of dynamically changing the SHTCs on two sides. For a typical day in winter, the maximum relative deviation of $-20.9 \%$ was observed at Lhasa with $\varphi=0.29$. However, for a typical summer day, the absolute value of the relative deviation in $X_{i}$ 'an and Beijing was lower than 3.0\%. Thus, for these cities, selecting different SHTCs had little influence on the cumulative heating load results on a typical summer day. However, for the other three cities, the differences could not be ignored at $\varphi=0.49$, where the relative deviations were larger than $20 \%$.

Boxplots showing the relative deviations in the daily cumulative load on a typical day with different SHTCs are shown in Figure 10. According to the results presented above for the cumulative heating and cooling load on a typical day, the relative deviation was influenced by different climate conditions and building shape factors. When dynamic internal SHTCs were employed, the relative deviation with $\varphi=0.49$ was larger than the results obtained with $\varphi=0.29$ for the selected cities. However, the results were reversed for the external SHTCs. The comprehensive effect was integrated based on the internal and external sides, and it was affected more by the side with the larger relative deviation.

\subsection{Correction of Annual Cumulative Load}

Based on the daily cumulative load behaviors obtained using different SHTCs, the annual cumulative heating and cooling load corrections were determined. The annual cumulative loads with various internal and external SHTCs are illustrated in Figure 11. The annual cumulative loads were mainly determined by the daily cumulative load results on a typical day. However, the annual cumulative loads were affected mainly by the climate conditions during transition seasons. Therefore, the deviations between the internal and external sides, two different shape factors, and cooling and heating loads are shown in Figure 11. 


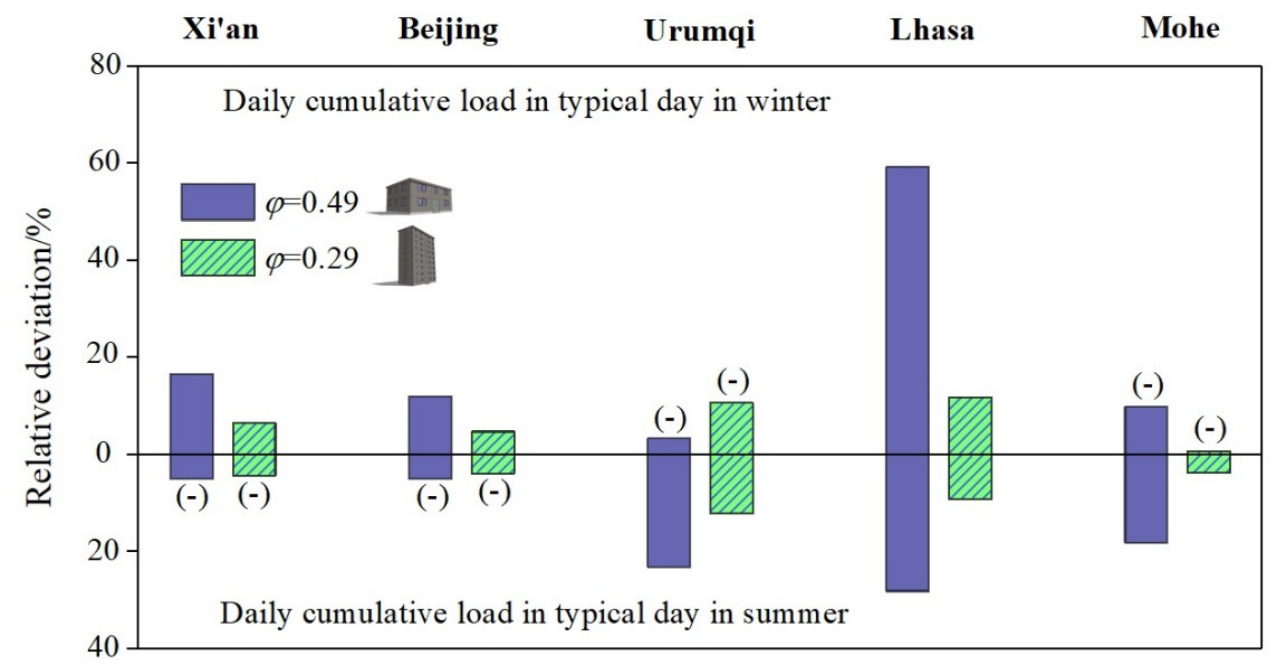

(a)

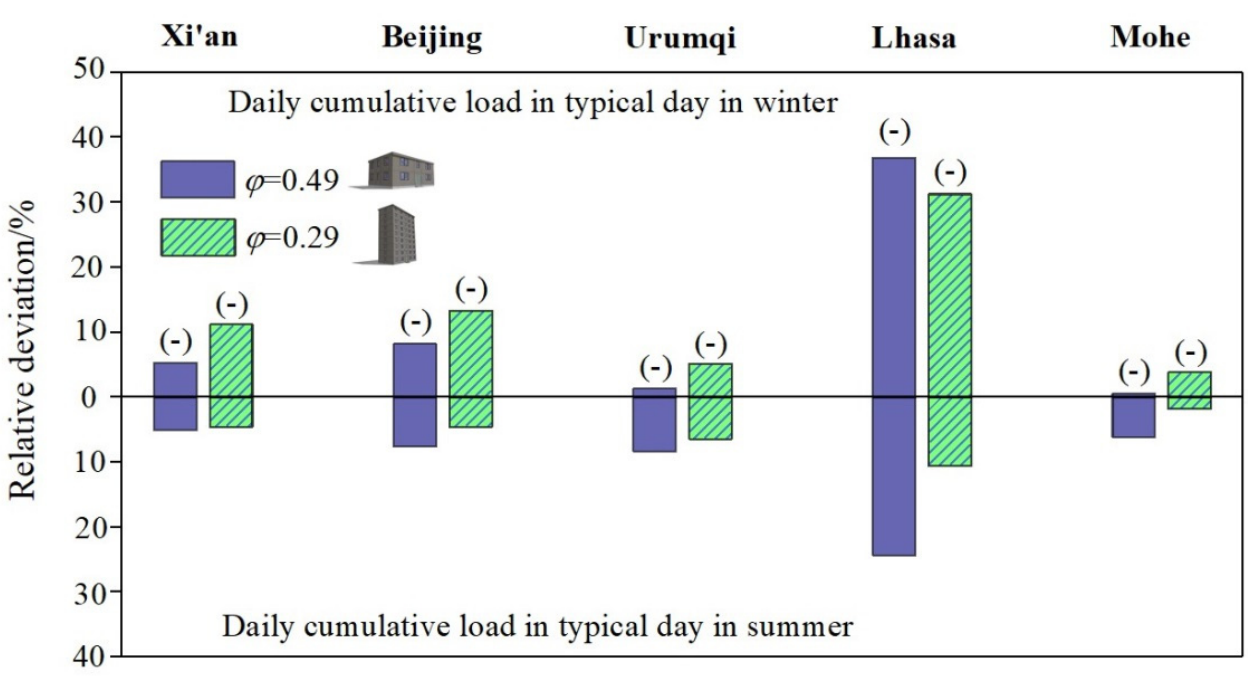

(b)

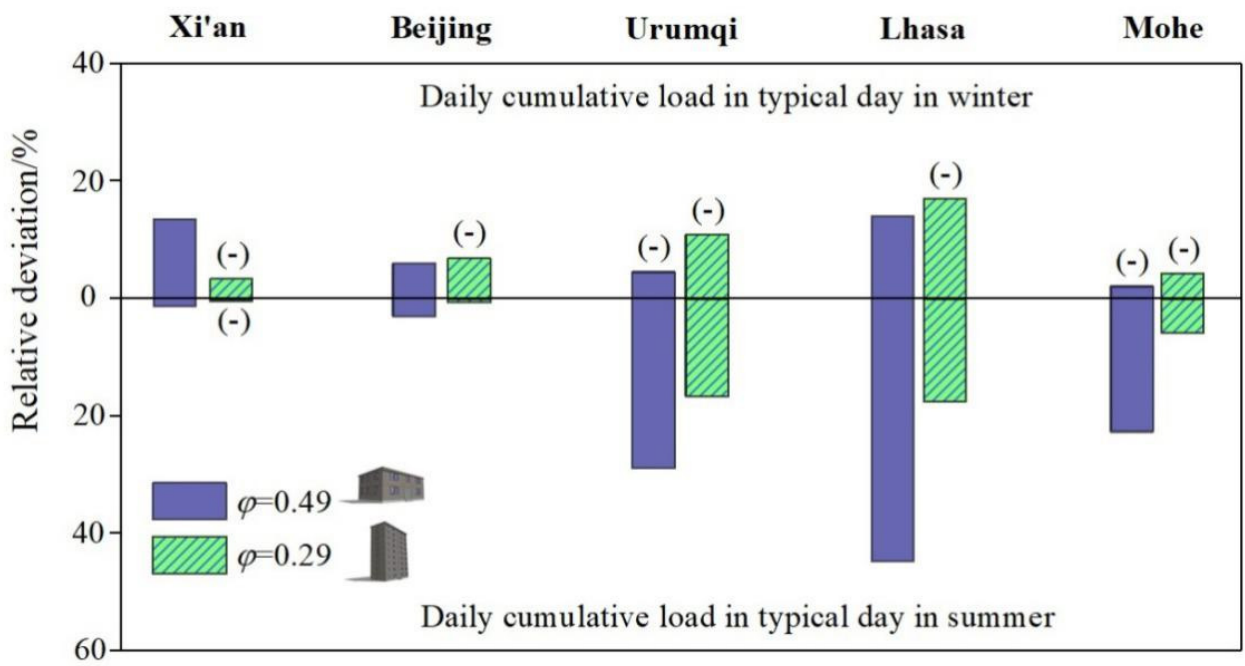

(c)

Figure 9. Comparisons of daily cumulative loads with different SHTCs on a typical day: (a) Indoor side with the TARP model; (b) Outdoor side with the TARP model; (c) Both sides with the TARP model. 


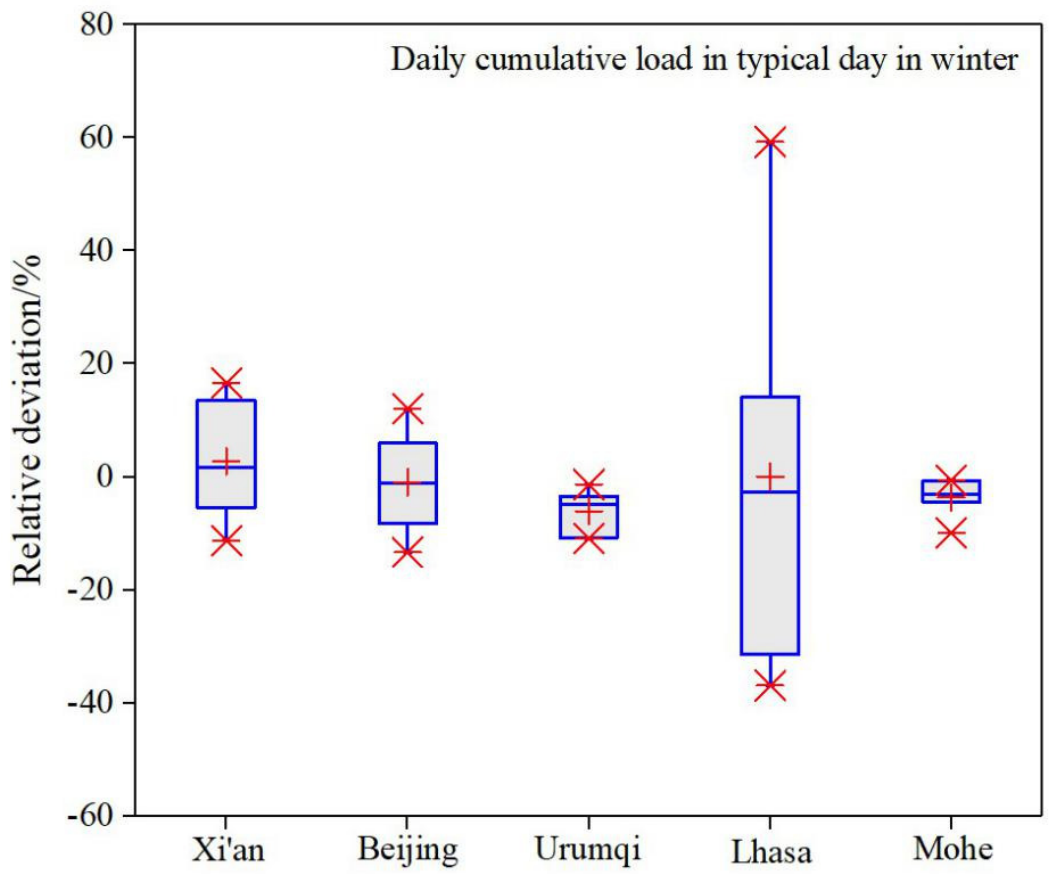

(a)

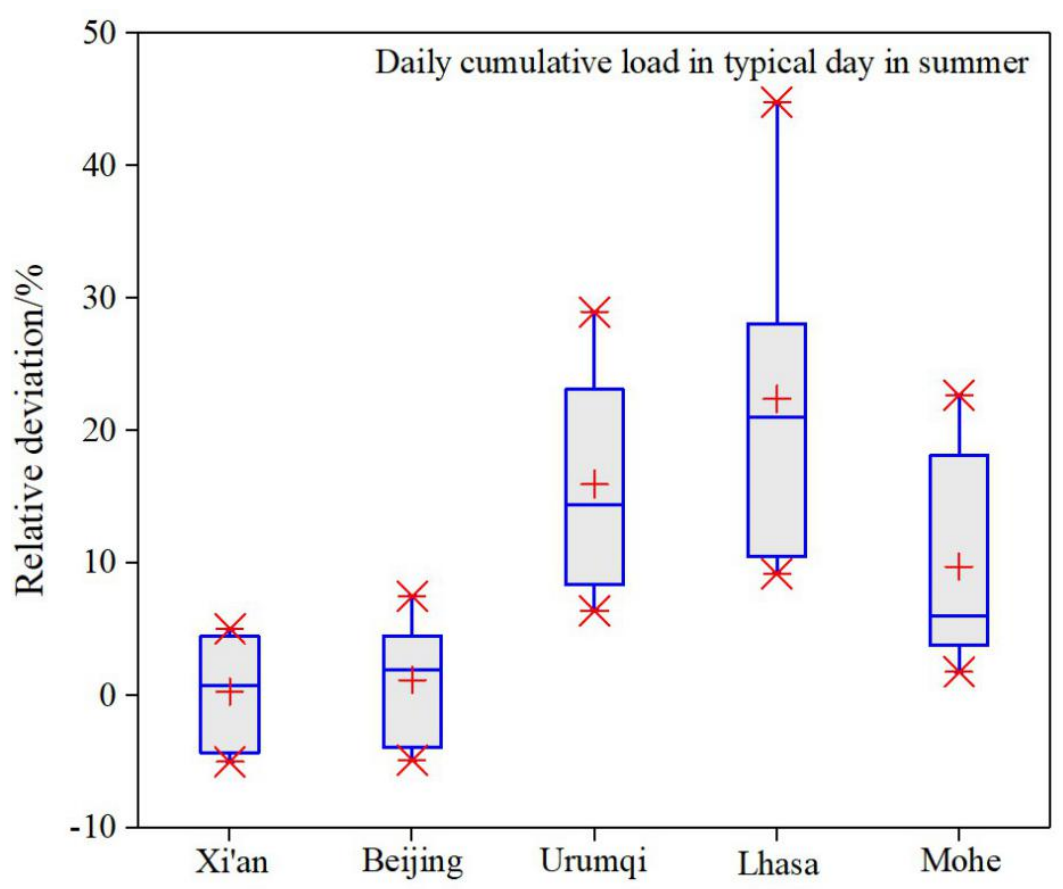

(b)

Figure 10. Boxplots showing the relative deviations in the daily cumulative load on a typical day with different SHTCs: (a) Daily cumulative load on a typical day in winter; (b) Daily cumulative load on a typical day in summer. 


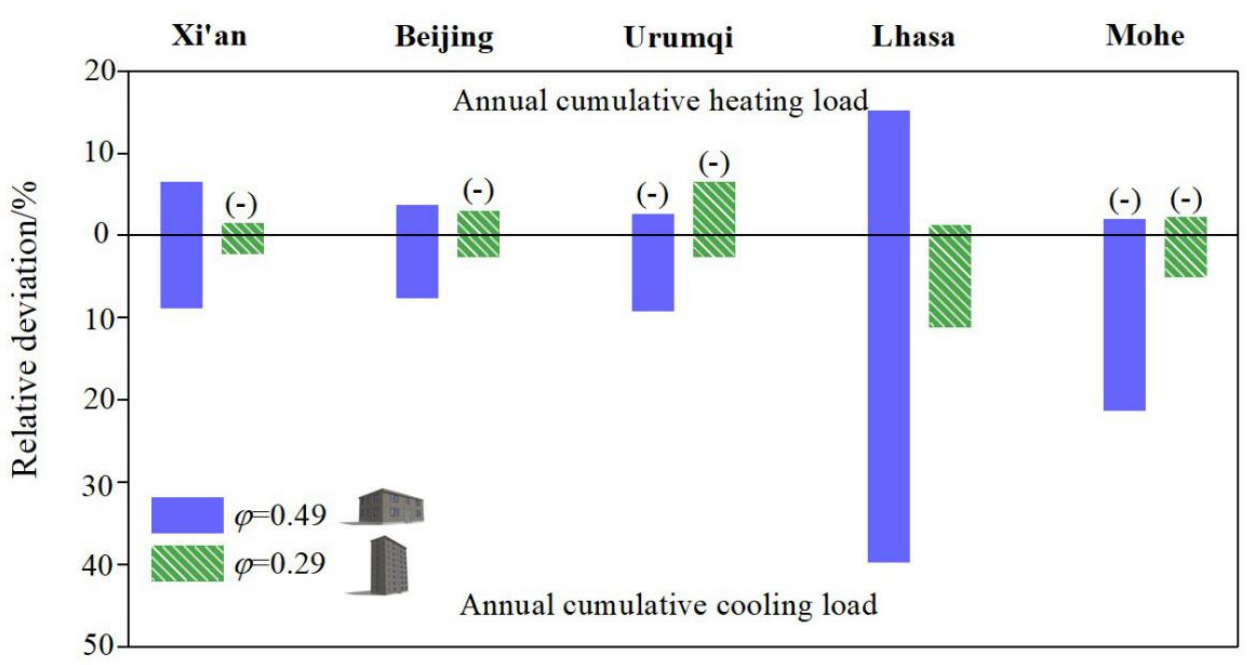

(a)

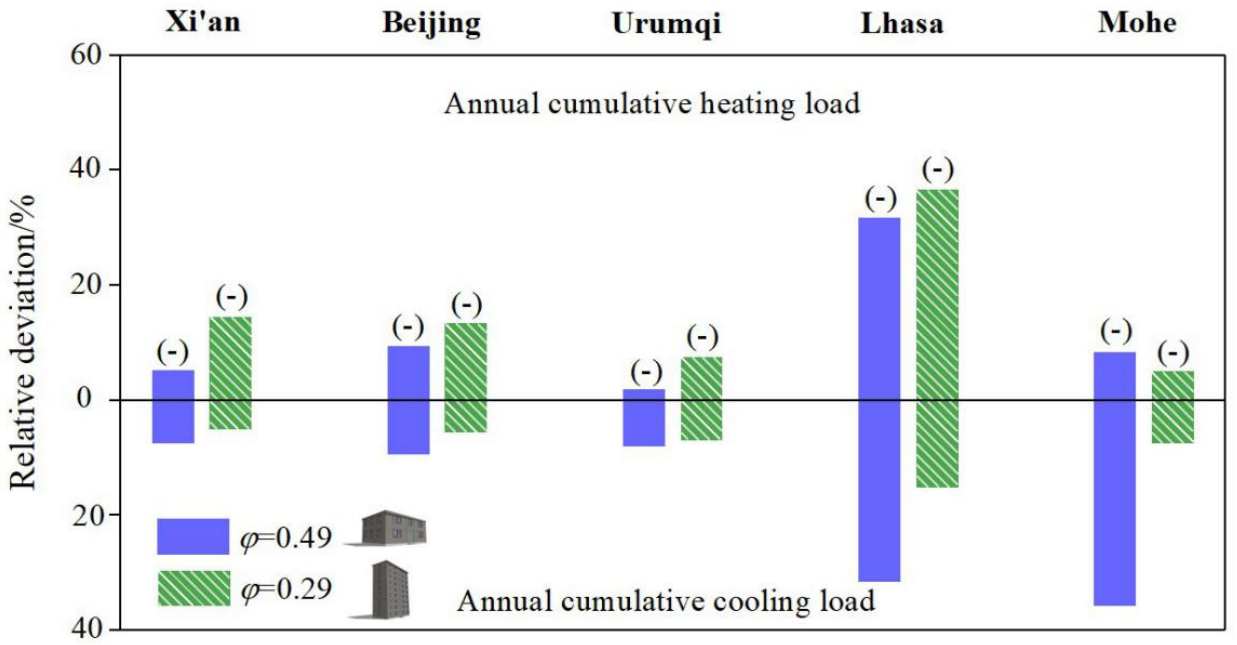

(b)

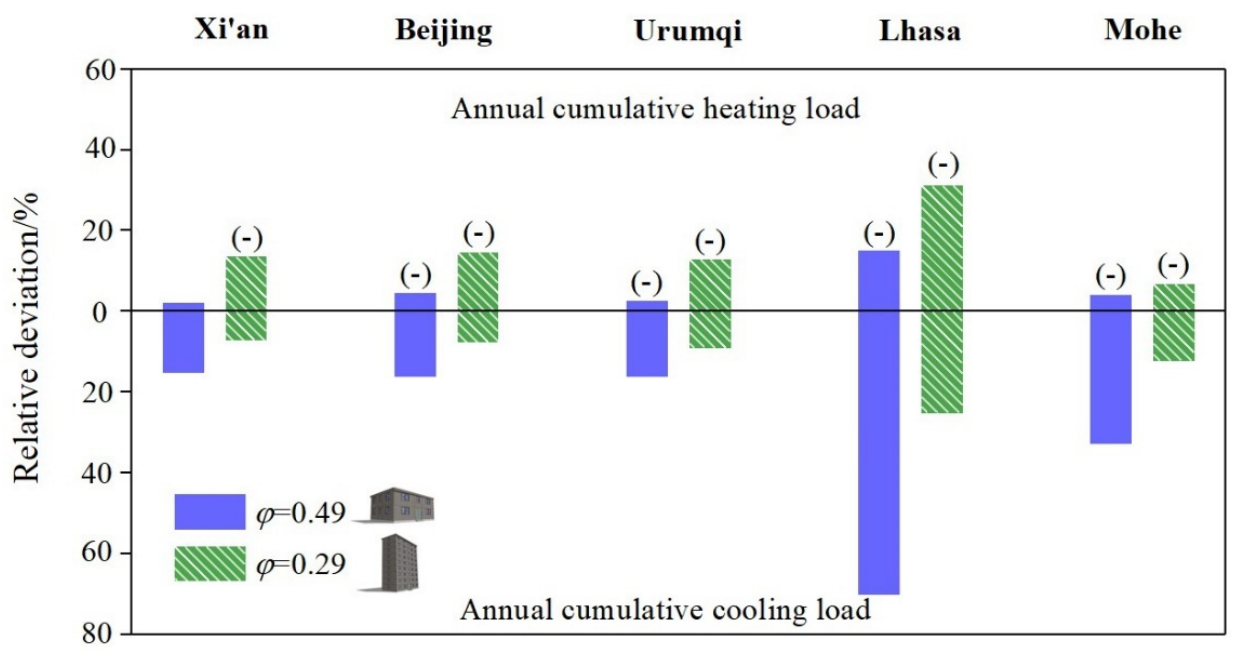

(c)

Figure 11. Comparisons of annual cumulative loads with different internal and external SHTCs: (a) Indoor side with the TARP model; (b) Outdoor side with the TARP model; (c) Both sides with the TARP model. 
Boxplots representing the relative deviations in the annual cumulative heating and cooling loads with different SHTCs are shown in Figure 12. The deviations in the heating loads were considerable in $\mathrm{Xi}^{\prime}$ an, Beijing, and Lhasa. The relative deviation even ranged from $41.5 \%$ to $15.0 \%$ because Lhasa is located on the Tibetan Plateau. The traditional approach for predicting the building cooling load using constant SHTCs was not accurate, especially in Lhasa and Mohe because Lhasa is located on the Tibetan Plateau and Mohe is at the highest latitude.

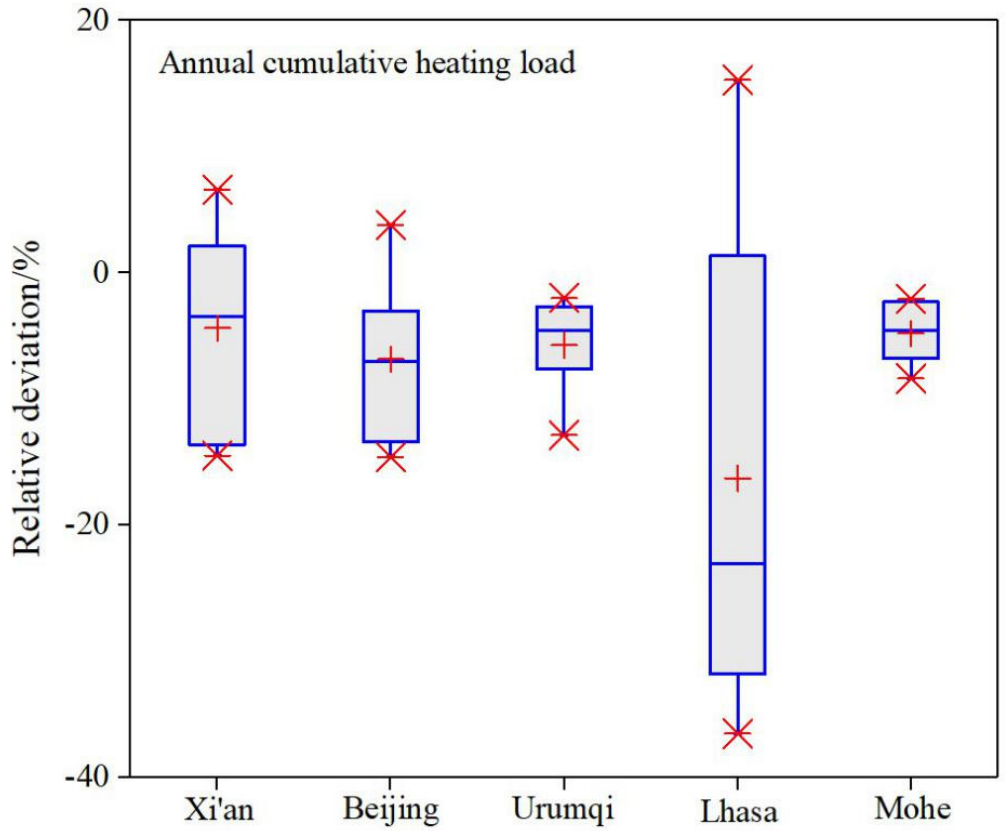

(a)

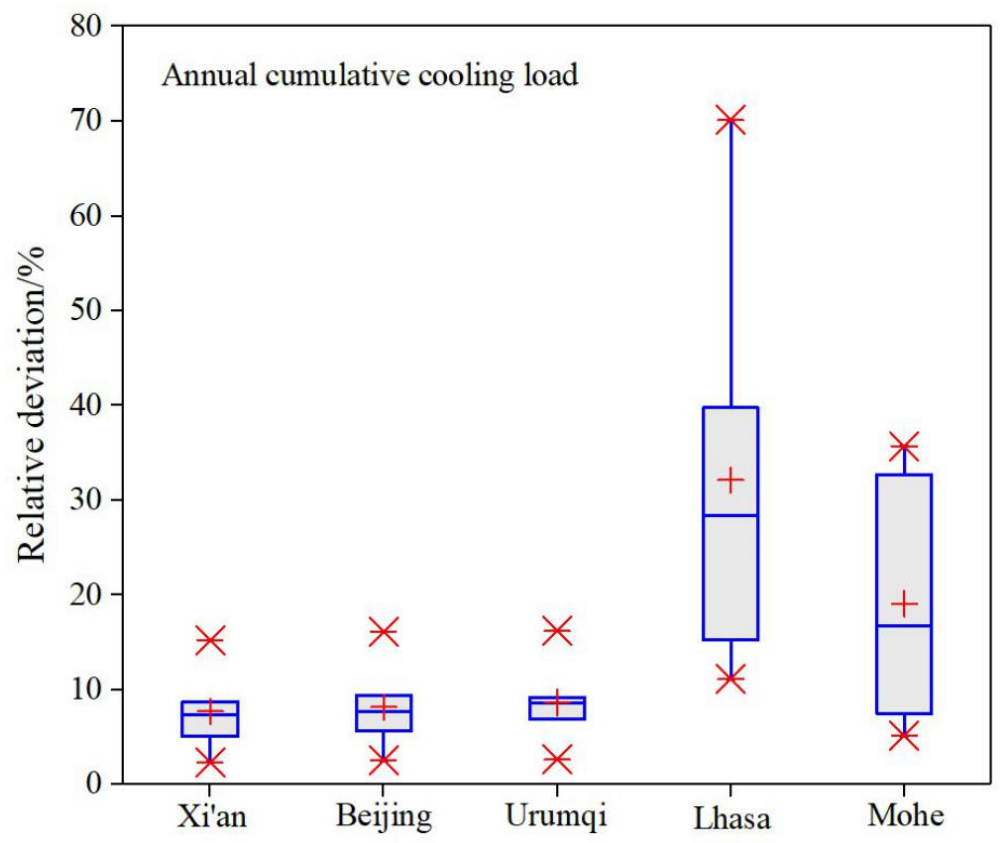

(b)

Figure 12. Boxplots showing the relative deviations in the annual cumulative heating and cooling loads with different SHTCs: (a) Annual cumulative heating loads; (b) Annual cumulative cooling loads. 


\subsection{Correction of Annual Cumulative Load}

The current systems are based on constant SHTCs but the actual situation is closer to the TARP model. Therefore, it is useful to obtain the actual deviation values according to the different SHTCs for early-stage office building design. Furthermore, in the current trade-off option for building energy efficiency, the assessment is based on comparing the actual annual energy consumption and the reference building models. Therefore, correction is also conducted based on the annual building load.

The annual building load $(Q)$ was carefully compared under the two conditions with TARP-based SHTCs and the current methods in the national standard (Design standard for energy efficiency of public buildings (GB 50189-2015)), as shown in Figure 13. The relative deviation was less than $5 \%$ under the two different shape factors for Mohe in a severely cold zone (Figure 13). Thus, correction is not necessary for actual engineering applications in areas where the climate is similar to Mohe. In Xi'an, Beijing, and Urumqi, the relative deviations with shape factors of 0.49 and 0.29 were around $10 \%$ and $5 \%$, respectively. Thus, the correction factor should be considered for these cities to obtain more accurate results. In Lhasa, the relative factors were $67.5 \%$ and $25.3 \%$ with shape factors of 0.49 and 0.29 , respectively. Thus, the results should be corrected and the results obtained with constant SHTCs are no longer applicable in areas where the climate is similar to Lhasa.

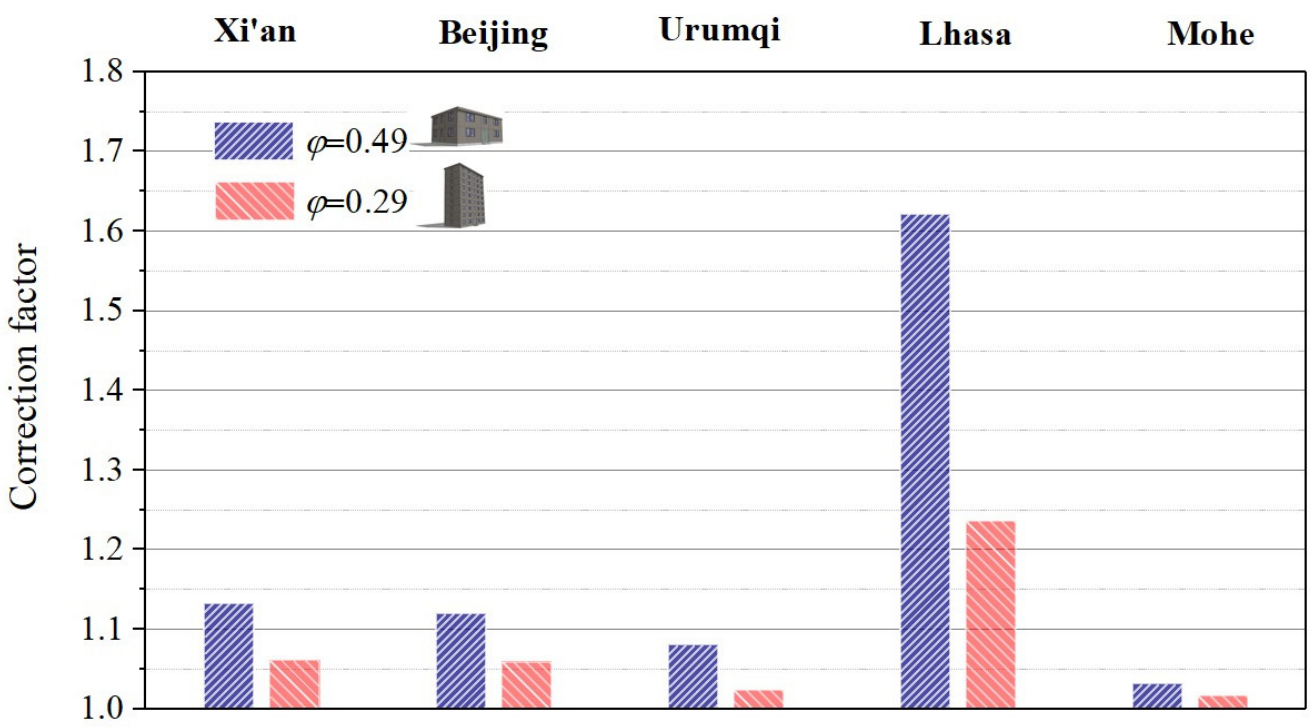

Figure 13. Relative deviations in annual cumulative load for five typical cities in China.

The correction is based on the current building energy efficiency systems in China. The steady-state method and constant SHTCs are employed according to the specific engineering needs and computational conditions. Therefore, the results obtained with constant SHTCs should be corrected with the correction factor to increase their accuracy. The demand for early-stage designs of energy-efficient office buildings has been increasing recently. Thus, improvements can be made by applying unsteady-state methods and dynamically changing SHTCs. The quantitative differences in the results obtained with different SHTCs were determined in the present study, thereby providing an essential reference for developer and publishers of standards for building energy efficiency.

\section{Conclusions}

In the present study, a building load-based trade-off option was established for energy-efficient building design to address the limitations of the current building energy consumption-based trade-off option. A scientific research method was applied to determine the building energy efficiency and building simulations were conducted, where the actual building energy efficiency situation in China was adequately considered. Accord- 
ing to the related standards, two representative buildings were considered to investigate the hourly load behavior on a typical day, daily cumulative load on a typical day, and annual cumulative loads with different SHTCs. The main conclusions obtained in this study are as follows.

(1) The hourly building loads on a typical day determined with the TARP model clearly differed from those obtained with the traditional approach. In most conditions, the relative deviation increased as the shape factor increased.

(2) Corrections were obtained for the annual cumulative loads based on the relative deviations between the results produced by the TARP model and with the traditional constant SHTCs. The correction factors were determined as $67.5 \%$ and $25.3 \%$ for Lhasa with $\varphi=0.49$ and 0.29 , respectively. In Xi'an and Beijing, the correction factors determined with $\varphi=0.49$ were $13.3 \%$ and $12.0 \%$, respectively. The correction factors were lower than $5.0 \%$ for other conditions, thereby indicating that no corrections are required.

(3) The SHTCs and shape factors are readily available types of information that can be used for decision making in the early stages of building design, and they will clearly influence the energy performance of a building through the design stage.

Author Contributions: Conceptualization, Y.W. and T.Z.; methodology, Y.W. and T.Z.; software, Y.W. and W.J.; validation, L.Y.; formal analysis, Y.W. and L.Y.; investigation, Y.L.; resources, L.Y. and T.Z.; data curation, Y.W., W.J., L.Y. and Y.L.; writing-original draft preparation, Y.W. and T.Z.; writing-review and editing, L.Y. and T.Z.; visualization, W.J. and Y.L.; supervision, L.Y.; project administration, Y.W. and W.J.; funding acquisition, Y.W. and T.Z. All authors have read and agreed to the published version of the manuscript.

Funding: This research was supported by the Natural Science Foundation of China (No. 51974218), Independent Research and Development project of State Key Laboratory of Green Building in Western China (No. LSZZ202005), and Laboratory Foundation of Shaanxi Provincial Department of Education (21JS031).

Institutional Review Board Statement: Not applicable.

Informed Consent Statement: Not applicable.

Data Availability Statement: The data used to support the findings of this study are available from the corresponding author upon request.

Conflicts of Interest: The authors have no conflict of interest to declare.

\section{References}

1. Building Energy Conservation Research Center. China Building Energy Efficiency Annual Development Report; Tsinghua University Press: Beijing, China, 2020. (In Chinese)

2. Cui, Y.; Yan, D.; Hong, T.Z.; Ma, J.J. Temporal and spatial characteristics of the urban heat island in Beijing and the impact on building design and energy performance. Energy 2017, 130, 286-297. [CrossRef]

3. Peng, L.; Liu, J.P.; Wang, Y.; Chan, P.W.; Lee, T.C.; Peng, F.; Wong, M.; Li, Y. Wind weakening in a dense high-rise city due to over nearly five decades of urbanization. Build. Environ. 2018, 138, 207-220. [CrossRef]

4. Liu, Y.; Yang, L.; Zheng, W.X.; Liu, T.; Zhang, X.R.; Liu, J.P. A novel building energy efficiency evaluation index: Establishment of calculation model and application. Energy Convers. Manag. 2018, 166, 522-533. [CrossRef]

5. Yuan, Y.; Yu, X.; Yang, X.; Xiao, Y.; Xiang, B.; Wang, Y. Bionic building energy efficiency and bionic green architecture: A review. Renew. Sustain. Energy Rev. 2017, 74, 771-787. [CrossRef]

6. Delgarm, N.; Sajadi, B.; Kowsary, F.; Delgarm, S. Multi-objective optimization of the building energy performance: A simulationbased approach by means of particle swarm optimization (PSO). Appl. Energy 2016, 170, 293-303. [CrossRef]

7. Delgarm, N.; Sajadi, B.; Delgarm, S. Multi-objective optimization of building energy performance and indoor thermal comfort: A new method using artificial bee colony (ABC). Energy Build. 2016, 131, 42-53. [CrossRef]

8. Zhu, D.D.; Hong, T.Z.; Yan, D.; Wang, C. A detailed loads comparison of three building energy modeling programs: EnergyPlus, DeST and DOE-2.1E. Build. Simul. 2013, 6, 323-335. [CrossRef]

9. Liu, J.Y.; Heidarinejad, M.; Gracik, S.; Srebric, J. The impact of exterior surface convective heat transfer coefficients on the building energy consumption in urban neighborhoods with different plan area densities. Energy Build. 2015, 86, 449-463. [CrossRef] 
10. Mirsadeghi, M.; Cóstola, D.; Blocken, B.; Hensen, J.L.M. Review of external convective heat transfer coefficient models in building energy simulation programs: Implementation and uncertainty. Appl. Therm. Eng. 2013, 56, 134-151. [CrossRef]

11. Wijeysundera, N.E.; Chou, S.K.; Jayamaha, S.E.G. Heat flow through walls under transient rain conditions. J. Build. Phys. 1993, 17, 118-141. [CrossRef]

12. Liu, J.Y.; Heidarinejad, M.; Gracik, S.; Srebric, J.; Yu, N.Y. An indirect validation of convective heat transfer coefficients (CHTCs) for external building surfaces in an actual urban environment. Build. Simul. 2015, 8, 337-352. [CrossRef]

13. Hagishima, A.; Tanimoto, J. Field measurements for estimating the convective heat transfer coefficient at building surfaces. Build. Environ. 2003, 38, 873-881. [CrossRef]

14. Loveday, D.L.; Taki, A.H. Convective heat transfer coefficients at a plane surface on a full-scale building façade. Int. J. Heat Mass Transf. 1996, 39, 1729-1742. [CrossRef]

15. McAdams, W.H. Heat Transmission; McGraw-Hill Kogakusha: Tokyo, Japan, 1954.

16. Sturrock, N.S. Localised Boundary Layer Heat Transfer from External Building Surfaces. Ph.D. Thesis, University of Liverpool, Liverpool, UK, 1971.

17. Yang, W.; Zhu, X.; Liu, J. Annual experimental research on convective heat transfer coefficient of exterior surface of building external wall. Energy Build. 2017, 155, 207-214. [CrossRef]

18. Koca, A.; Çetin, G. Experimental investigation on the heat transfer coefficients of radiant heating systems: Wall, ceiling and wall-ceiling integration. Energy Build. 2017, 148, 311-326. [CrossRef]

19. Yang, L.; Qiao, Y.H.; Liu, Y.; Zhang, X.R.; Zhang, C.; Liu, J.P. A kind of PCMs-based lightweight wallboards: Artificial controlled condition experiments and thermal design method investigation. Build. Environ. 2018, 144, 194-207. [CrossRef]

20. Anderson, J.S. Energy use excellence and the building envelope. J. Green Build. 2019, 14, 179-204. [CrossRef]

21. Guo, R.; Hu, Y.; Heiselberg, P.; Johra, H.; Zhang, C.; Peng, P. Simulation and optimization of night cooling with diffuse ceiling ventilation and mixing ventilation in a cold climate. Renew. Energy 2021, 179, 488-501. [CrossRef]

22. Liu, J.; Zhu, S.; Kim, M.K.; Srebric, J. A Review of CFD Analysis Methods for Personalized Ventilation (PV) in Indoor Built Environments. Sustainability 2019, 11, 4166. [CrossRef]

23. Kahsay, M.T.; Bitsuamlak, G.; Tariku, F. Numerical analysis of convective heat transfer coefficient for building facades. J. Build. Phys. 2019, 42, 727-749. [CrossRef]

24. Blocken, B.; Defraeye, T.; Derome, D.; Carmeliet, J. High-resolution CFD simulations for forced convective heat transfer coefficients at the facade of a low-rise building. Build. Environ. 2009, 44, 2396-2412. [CrossRef]

25. Kahsay, M.T.; Bitsuamlak, G.; Tariku, F. Effect of localized exterior convective heat transfer on high-rise building energy consumption. Build. Simul. Int. J. 2020, 13, 127-139. [CrossRef]

26. Montazeri, H.; Blocken, B. New generalized expressions for forced convective heat transfer coefficients at building facades and roofs. Build. Environ. 2017, 119, 153-168. [CrossRef]

27. Iousef, S.; Montazeri, H.; Blocken, B.; van Wesemael, P.J.V.V. On the use of non-conformal grids for economic LES of wind flow and convective heat transfer for a wall-mounted cube. Build. Environ. 2017, 119, 44-61. [CrossRef]

28. Montazeri, H.; Blocken, B. Extension of generalized forced convective heat transfer coefficient expressions for isolated buildings taking into account oblique wind directions. Build. Environ. 2018, 140, 194-208. [CrossRef]

29. Costanzo, V.; Evola, G.; Marletta, L.; Gagliano, A. Proper evaluation of the external convective heat transfer for the thermal analysis of cool roofs. Energy Build. 2014, 77, 467-477. [CrossRef]

30. Sayin, S.; Augenbroe, G. Optimal energy design and retrofit recommendations for the turkish building sector. J. Green Build. 2021, 16, 61-90. [CrossRef]

31. EnergyPlus. EnergyPlus Version 8.7 Documentation: Engineering Reference; United States Department of Energy: Washington, DC, USA, 2013.

32. Rowley, F.B.; Eckley, W.A. Surface coefficients as affected by wind direction. ASHRAE Trans. 2018, 38, 33-46.

33. Fox, J.; Osmond, P.; Peters, A. The Effect of Building Facades on Outdoor Microclimate-Reflectance Recovery from Terrestrial Multispectral Images Using a Robust Empirical Line Method. Climate 2018, 6, 56. [CrossRef]

34. Bauman, F.; Andersson, B.; Carroll, W.L.; Kammerud, R.; Friedman, N.E. Verification of BLAST by Comparison with Measurements of a Solar-Dominated Test Cell and a Thermally Massive Building. J. Sol. Energy Eng. 1983, 105, 207-216. [CrossRef]

35. Yuill, G.K. Computer modeling: The BLAST verification. ASHRAE J. 1986, 28, 62-70.

36. Walton, G.N. Thermal Analysis Research Program-Reference Manual. National Technical Reports Library. 1983. Available online: https:/ /ntrl.ntis.gov/NTRL/dashboard/searchResults/titleDetail/PB83194225.xhtml (accessed on 26 June 2018).

37. Zmeureanu, R.; Fazio, P.; Haghighat, F. Analytical and inter-program validation of a building thermal model. Energy Build. 1987, 10, 121-133. [CrossRef]

38. ISO 6946:2017. Building Components and Building Elements-Thermal Resistance and Thermal Transmittance-Calculation Methods; NSAI: Geneva, Switzerland, 2017.

39. Energy Do. Available online: https:/ / www.energyplus.net/2018 (accessed on 26 June 2018).

40. Available online: http://apps1.eere.energy.gov/buildings/energyplus/cfm/weather_data3.cfm (accessed on 10 March 2018). 